EW I N G

Stulies on the Acarina of Illinois

Entomology

$A B$
1906

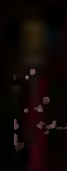

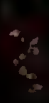

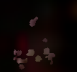

5

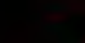




N

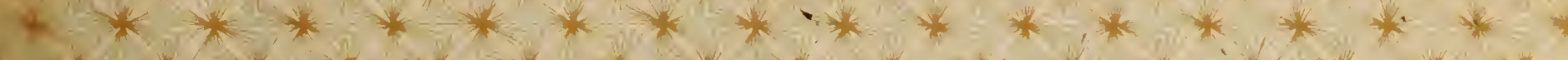

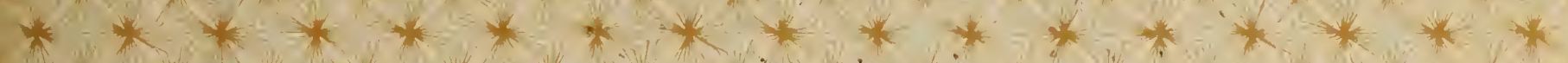

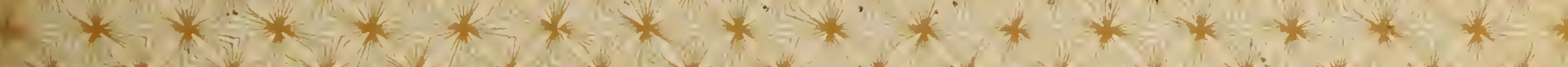

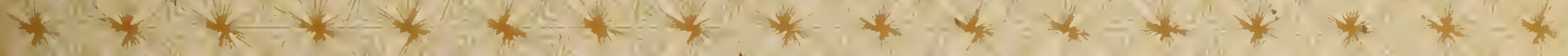

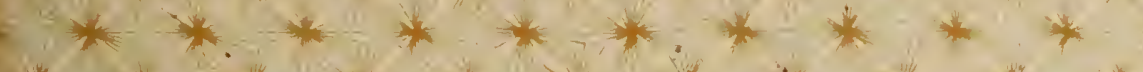

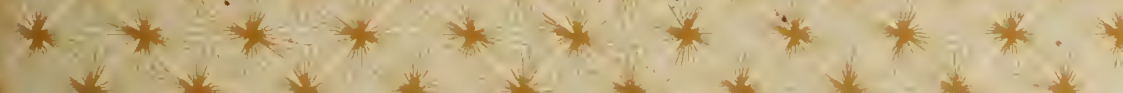

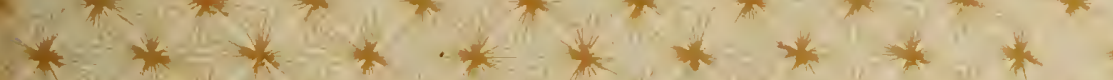

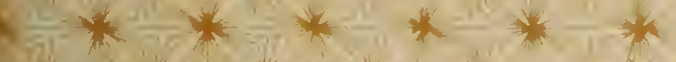
M

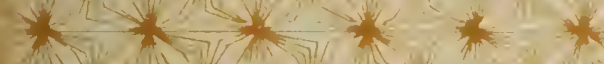

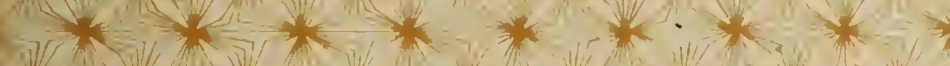

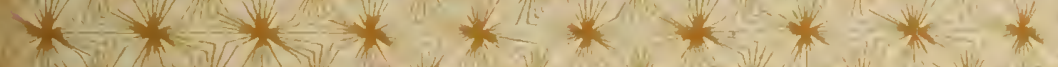
a

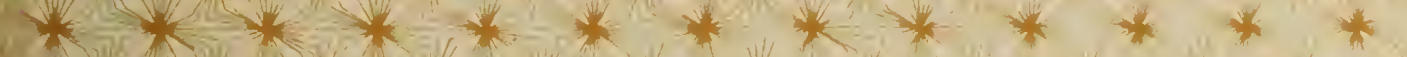

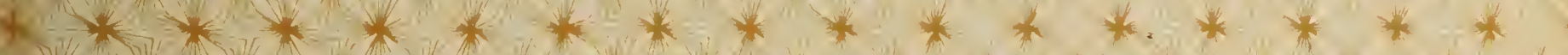

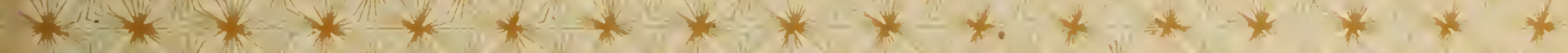

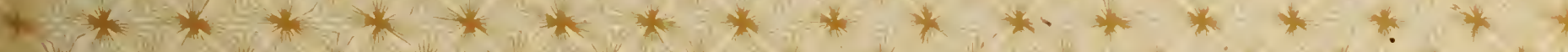

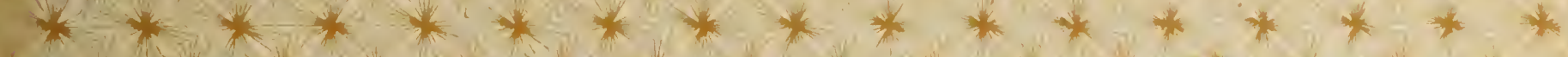

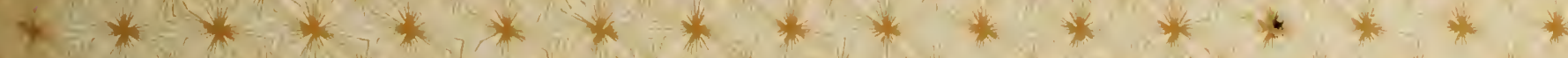

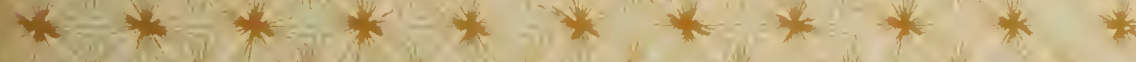

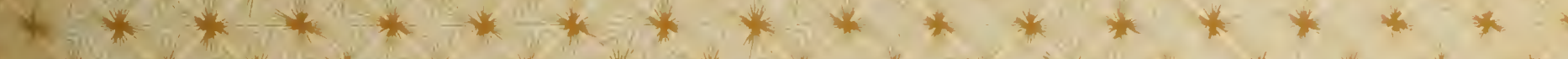

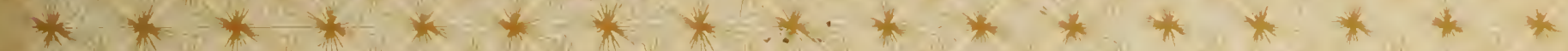

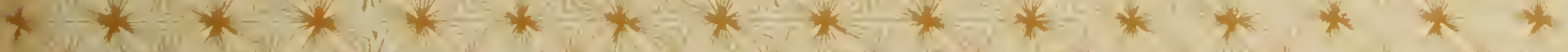

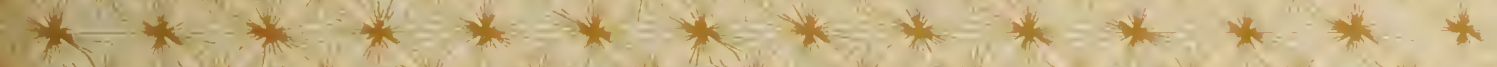

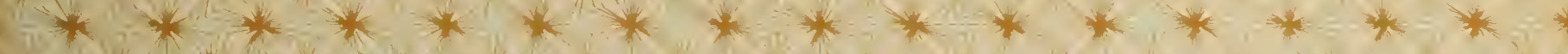

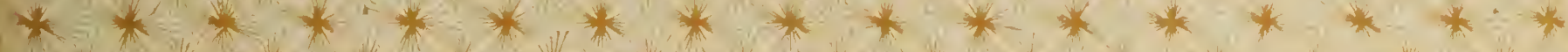

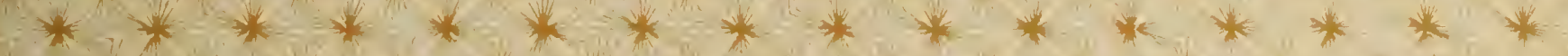

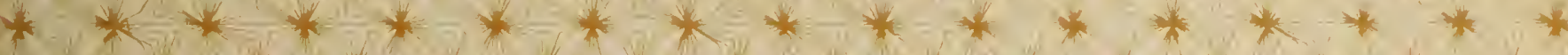

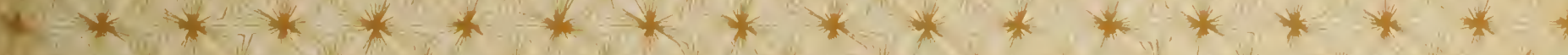

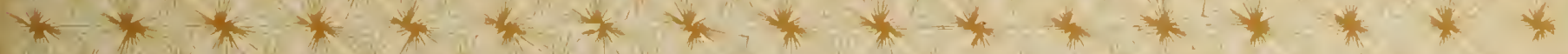

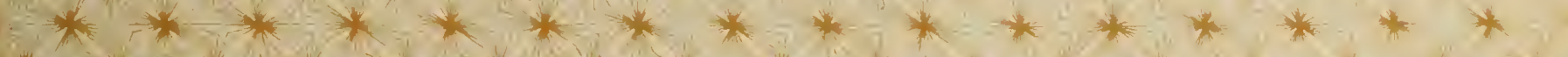

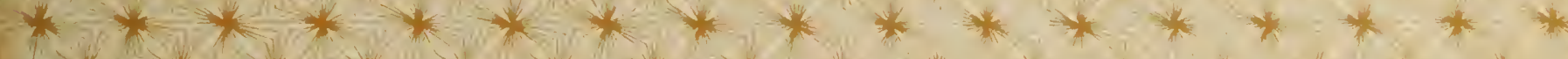

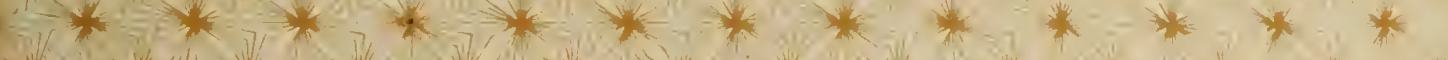

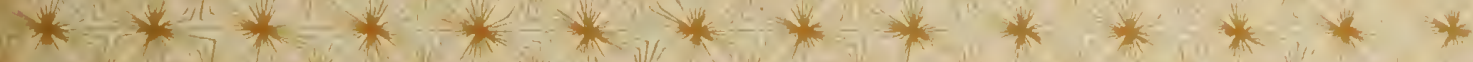

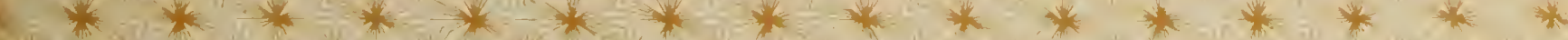

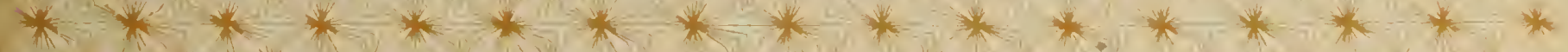

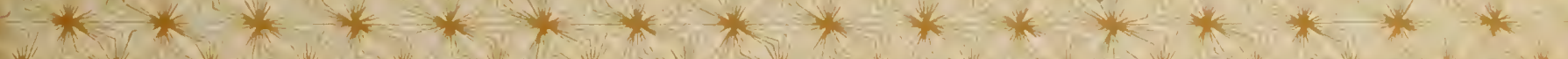

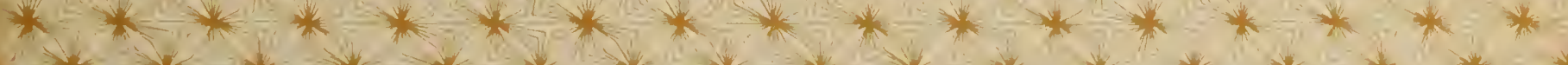

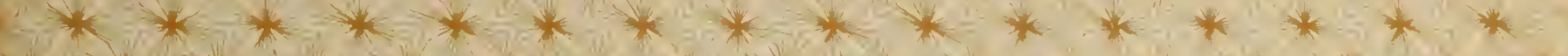

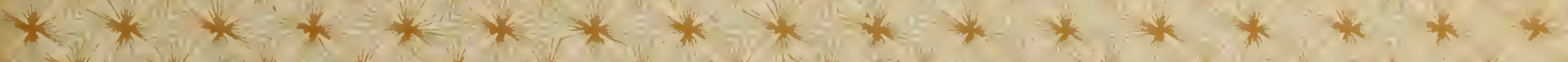
D.

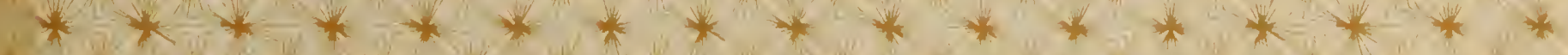

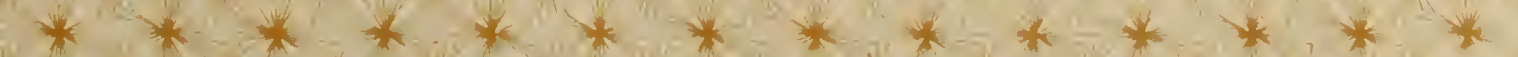





\title{
STUDIES ON THE ACARINA OF ILLINOIS
}

\author{
BY \\ HENRY ELLSWORTH "EWING
}

THESIS

For the Degree of Bachelor of Arts

in Entomology

COLLEGE OF SCIENCE

UNIVERSITY OF ILLINOIS

1906 
$b+\ldots+-\ldots+\cdots+\cdots+\cdots+\cdots$ 
THIS IS TO CERTIFY THAT THE THESIS PREPARED UNDER MY SUPERVISION BY

Henry Ellsworth Ewing,

ENTITLED Studies on the Acarina of Illinois

IS APPROVED BY ME AS FULFILLING THIS PART OF THE REQUIREMENTS FOR THE DEGREE of Bachelor of Arts.

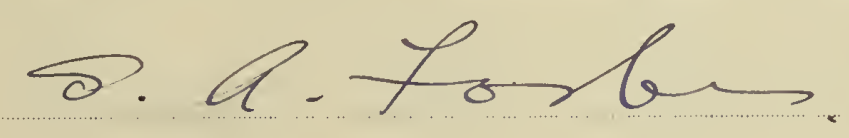

HEAD OF DEPARTMENT OF ZOOIOgY. 

CONTENTS.

\section{Page}

INTRODUCTION $\ldots \ldots \ldots \ldots \ldots$ I

METHODS $\ldots \ldots \ldots \ldots \ldots \ldots \ldots 4$

CLASSIFICATION ......... 8

HABI'IS .............. 16

LIFE HISTORY .......... 20

ANATOMY .............. 26

DESCRIPTION OF SPECIES .... 31

GLOSSAFY . . . . . . . . . 68

BIBLIOGRAPIYY .......... 76

ABBREVIATIONS $\ldots \ldots \ldots \ldots . . .87$

EXPIAANATION OF PLATES ..... 91

PIATES 
Digitized by the Internet Archive in 2013

http://archive.org/details/studiesonacarina00ewin 
- INTRODUCTION.

The Acarina, or mites, have always been an interesting group to the biologist. Their peculiar habits, their economic importance, wh the ir whiec and often complex life histories afford an excelient field for investigation. Their economic importance is such as to attract the attention of many specia.l studentg. Some of the Acarina are beneticial, - for example, Trombidium locustarium, the larva of which is parasitic on common grasshoppers and the adult of which lives largely on grasshopper eggs. Several species of mites are known to eat plant lice and are therefore beneficial. Yet perhaps the majority of the Acarina are injurious, directIy or indrectiy. Ganasilie aro Ixodidae are parasitic, often orestic animals and poultry. The cattle ticks (Ixoilaae) are known to transmit certain disease:. Some mites are parastife on ves; others Iive in the skin of animals and man. The itch mites have long been known as hurnan pests. Many of the "runring sores" of domestic animals are due to mites. Some mites do great dinage to piants; trus zome species of Trombidium destroy garden plants. Then there are the "gall mites" which inflict considerable injury upon trees as well as other plants.

Few classes of animas have as mide a distribution as mites. They have been found in all parts of the known world and in most places abundantly. Mites are found not only in all parts of the earth but live underery difierent conitions in the same locality. 

Many mites are aquatic, many are parasitic, Iivirg on mamais, birds, rishes and insects; others are found on the leaves of trees, under rocks, bociris, I0x, moss, dead ieaves and rubbish.

Among the earliest investigators to be attracted to the study of mites were the following: Müller, who studied the aquatic forns; Geoprong in I7b2; Latreilie in 8bout 1ry5; 0. Fabricus at doout the same time; Hermann in 1804; Hevien in 1816; Dugès in 1834. Yet until the time of C. I. Koch, or about 1840, this preat field ol study was kut little explored. In his "Deutscriands Crustaceen, Miriopoden und Arachniden" (1835-'40) Koch describes and figures several hundrea species. II: thoroughly investigatei the mites of Germany drei hjs work forms the basis of much of our present classification. Several years later, A. Murraj, the first: English authority to investigate the field, devoted nearly 300 pages in his "Aptera" to the subject of mites. This book was for many years regarded as authoritive by English students. Of recent years there have been several distinguished European investigators of Acarind. A. D. Micrael, in his two volumes on "British Orihutidae", has covered that family very thoroughly. In "Das Tierreich", Iief. 3, 1898, Michael gives a key for the identificztion of species of oribatiale. In France, Nicolet in his "Acariens des Environs de Paris," describes and accurately figures many species. In Italy, A. Berlese and G. Conestrinthave ione axclimt, comprersive work on mites. In Norway, Thor has hescribed many species, especially of the family Bdellidae. I. Trägårdh has done much work on mites collected Irom Greenland, Spitzbergen, Siberia, Egypt, soudan and other parts of the world. In America the only investigator who 

has given much attention to mites is Nathan Banks. A few of the other well known students of Acarina are: G. Jeonardi, F. Fanzago, P. Kramer, E. Claparède, L. Karpelles, M. P. Megnin, E. Perrier

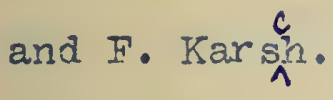

The Acarind form an order under the class Arachnida. Some authorities have endeavored to make a separate class of Acarina, but most authorities, however, do not believe that there are sufficient Erounds for ijleir separation as a class. The mites are related to the spiders in more ways than one: they have four pairs of legs, almost without exception, in the adult form; they have no distinct head and no antennae. Mites not only have a superficial resemblance to spiders but their habits and food in some cases are neariy iderilcal with those of spiders. The Tetranychinae, which affect plants, are popularly known as "red spiders" Many mites live on the eggs and larvæ of insects, and even upon other mites. 



\section{METHODS.}

Collecting. In making my collections several methods were used, depending upon the number of specimens desired and also upon the habits of the mites. For most purposes I used vials and canel's hair vrushes. By moistening the point of a brush and then applying it to a mite, the latter could be transferred to a vial. This method succeds with mites which have a hard or leathery integument but is often disastrous to small and soft species. In collecting the latter, one should not moisten the brush, since it adheres to the specimens so strongly that the latter cannot be detached without distortion. When mites were found on leaves, moss, etc., these materials were taken to the laboratory for inspection vith a hand lens. Mites were often collected by jarring plants or other material over a wide mouthed bottle.

When large quantities of specimens were desired, two methods were used. The first of these is a method devised by A. Berlese, who employed an apparatus described in the "Entomological News" Vol. 27, No. 2, Feb. 1906, pp. 49-54. Following the directiong given by Berlese, we made a galvanized sheet iron boiler, cylindrical in shape and about two and a half feet long by fourteen inches in diameter. Inside this cylinder and extending its full length, was a large funnel, about one foot in diameter at the top and tapering to about three fourths of an inch in diameter at the bottom. The mouth of the funnel passed through the base of the boiler. In operation, the boiler was filled with 

water which was kept at a temperature of about $80^{\circ}$ C. by means of a gas burner. The boiler was supported in an upright position by a tripod. Now a pan with a perforated bottom was placed over the top of the funnel and a bottle containing a little water was placed under the mouth of the funnel. The apparatus being ready, the material containing mites, and other small organisms was placed in the perforated pan. The mites upon feeling the warmth would go down through the holes in the bottom of the pan, and upon reaching the funnel would tumble down into the bottle, the funnel being too hot and too steep for the mites to remain long upon itg surface. Mites may thus be collected from soil, dead leaves, straw, grass, moss, manure, and debris of various kinds. A second method, which I employed with great success, was as follows: first, I would sift the mites from the materials in which they were contained, upon a white cloth (a large handkerchief is quite sufficient). This was done in the field. After a quantity of very fine debris containing minute organisms had thus been sifted upon the cloth, it was taken up and the contents poured into a large bottle. These siftings were taken to the laboratory and then poured out upon a hot plate, which was suspended over the top of a large funnel. The mites were driven out of the siftings by the intense heat and tumbled down through the furrel into a large bottle containing a little water, which prevented the mites from crawling out of the bottle. This method has several advantages over the Berlese method: first, it does avay with the necessity of carrying home a large amount of material; second, an immense number of mites can be quickly coliected in a smali bottle, thus permitting one to gather large quantities of specimens in a short time; third, no dirt comes down 

through the funnel along with the specimens. By the Berlese method, much dirt gets through the perforated pan into the collecting bottle.

Killing. Hot water or hot alcohol was used for killing specimens. The water or alcohol was first heated in a test tube and then poured into the collecting bottle upon the mites. The bottle should be immediately corked and well shaken. The hot water or alcohol causes the muscles to relax and the appendages to straighten out, so that the specimens are in excellent condition for dissection or for mounting.

Dissection. Many of the larger species were dissected, since without dissection it was impossible in many cases to use a high power lens to advantage.

Staining. Stains were often very useful with some of the smalier and more transparent forms. Various common stains were used, though eosin was generally preferred.

Mounting. The mounting of these minute arthropods is a rather deIicate piece of work. The use of steel instruments should be avoided,--a small camel's hair brush being preferable. When the cover glass is applied there is great danger of crushing the specimen; and even if the coverglass does not crush the specimen, it will often force the palpi, pseudostigmata, dorsal bristles, etc., out of their normal positions. It is best to elevate the cover glass on glass supports or on glass or rubber rings, though with sufficient care, good mounts of the harder species can be made wj.thout supporting the cover glass. Canada balsam was used for mounting the larger and harder specimens, and gljeerine jelly for the smaller and softer forms. I found 

considerable difficulty in mounting the softer forms in Canada balsam. For every species at least three mounts should be made,.. showing respectively the dorsal, ventral and lateral aspects.

Drawings. In making drawings, the proportions were obtained by the use of the Abbé camera luciaa. It was frequently desirable to use an oil immersion objective, especially in studying the mouth parts. Drawings were made from live specimens, as far as posible. 

CLASSIFICATION.

Order Acarina.

In Acarina the cephalothorax and abdomen are broadly united, the union being so complete that in many cases it is not visible. Four pairs of legs are rresent in the adult stage, with few exceptions (notably the Eriophyidae, which have but two pairs). Three pairs of legs are present in the nymph state, excepting Pteroptus, which has four pairs. Fyes are often present, sometimes consisting of only a median pair. The body is usually clothed with hairs or bristles. The mouth parts, consisting of mandibles and paipi, vary greatly in the different families. The maniibles are often chelate. Breathing is accomplished by means of a spiracie, situated usually at the sides of the body or clo se to the reck.

\section{Family Demodicidae.}

The body is wormlike; cephalothorax and abdomen united together without a line of demarkation. The palpi have three segments, the distal segment being hook-like; mandibles styliform. The trachae, stigmata and eyes are wanting. The larva are legless or else have triree pairs of very small legs. The nymph has four pairs or leg stumps and is without epimera and sternum. The adults have four pairs of legs, each leg having three segments. These forrs Iive in the skins of mammals. 

Family Friophyidae.

The members of this family have only two pairs of legs and each leg has five segnwu. The horg ras few hairs.Atruncated piece, it prapex of thabdomen). The abdomen terminates in a sucker. The cephalothorax often kears lines or ridges. Minute forms living on plants and orten prcoucing galls.

\section{Family Sarcoptidae.}

Body soft. Palpi small, three jointed. Ventral suckers usually present at genital opening or near anal opening. Eyes absent. Tarsi often with suckers. Rod-like epimera are present beneath the skin on the venter. Habits frequently parasitic. Subfamily Cytolichinae. There are no genitalkvulva Iongitudinal. The skin has fine parallel lines. These mites live in the skin and cellular tissues of birds.

Subfamily Sarcoptinae. There are no genital suckers. The skin bears parallel lines. Vulva transverse. Iiving in the skin of marnmals and birds.

Subfanily Analgesinae. No genital suckers. Skin with fine parallel lines. Parasitic on the plumage of birds.

Subfanily Listrophorinae. These mites possess special structural adaptations for clinging to the hairs of mammals. Genital suckers absent. Skin with fine parallel lines.

Subfamily Tyroglyphinae. Parasitic on bees only. Tarsi I and II with clavate hairs. Genital suckers usually present. 

Skin usualy without pine parallel jines. Tracheae absent.

Subfamily Canestrininae. Iegs short. They live on insects. Genital suckers present. Skin usually without fine parallel Iines. Trachae absent.

Subfamily Tarsoneminae. Forms with trachae. No ventral suckers. The legs end in claws. The body is divided into cephaIcthorax and abdomen. Not parasitic on hirds or marmals.

\section{Family Gamasillee.}

Forms having a distinct spiracle on each side of the body above the third or fourth coxa. Skin leathery. Tarsi usually with a sucker. Hypostc sme small; venter without furrows. Eyes absent. Generaily parasitic.

Subfamily Dermanyssinae. Mandibles fitted for piercirg. Body often constricted. Parasitic on vertebrates.

Subfamily Uropodinae. First pair of legs inserted within the same body opening as the oral tube. Genital apertures surrounded by sternum. Body orki or shield like. Iegs seldom extending much beyori tre masgin of the body. Mandibles slender. Usually there is a pedicel composed of excrement which serves to attach the uropoj to the insect. Usually attached to insects. Subfamily. Gamasinae. Generally they are parasitic on insects or vertebrates. Male genital aperture usually on the anterior margin of sternal viate. Body flat and broad. Eyes ahsent. There are many hairs on the legs and body. Mouth parts often retractle. Mandibles normally chelate. 



\section{Family Oribatidae.}

Cut lcula thoroughly chitinized. Cephalothorax and abdomen usually ajvided by a transverse constriction between the second and third pairs of I eEs. Tracheae usually present, simple and unbrached. Imnature forms without trachae. Stigmata, when eyisting, sunk in the acetabula of the coxae. Eyes absent. A pair of pseuriostignati, ecuh kearing a pseudo-stigmatic organ is present on the jorsa.i surfure of the cephalothorax. Handibles chelate, rarely serrate. Genital openings abdominal in both sexes. No exterral sexual diflerences of structure. Iarvae and nymphs with a soft or Ieathery cutjcula.

Subfamily Hoploderminae. Cephalothorax movably attached to abdomen. Palpi with four segments. Pteromorphae absent. Dorsal surface of cerhelothorax covered by a simple, more or less convex, chitinous plate. Ventrai plate rot anchylosed with the dorsal plate.

Subfamily Oribatinae. Abdomen with chitinous wing-like expansions (pteromorphae). Body globose or oblong.

Subfanily Apterogasterinae. Abjomen without wing-like expansions. Body of various forms.

Family Ixodidae.

A distinct spiracle is situated on each side of the body above or a Iitt Ie behind the third or the fourth coxa. PaIpi free Skin often coriaceous or leathery. Tarse often with suckers. Hypostc fe larege and furnished below with many recurved teeth. 

Venter with furrows. Skin leathery. The palpi are short and stout, indigtinct Iy composed of four segments. The genital opening is situated on the front of the sternal area slightly beyond the mouth orifice. The legs have six segments and arise close together. Parasitic un animis.

Subfamily Argasinae. Scutum and ventral shield absent. Mouth parts almost hidien from above. Stigmal plate between coxae III and IV.

Subfamily. Ixodinae. Scutum present. Ventral shields sometimes present. Mouth parts prominent from above. Stigmal plate behind coxae IV.

\section{Family Bdellidae.}

The cephalothorax and abdomen are distinct. The mandibles are large, forming a ieak. Body with few hairs. Palpi of four or five segments. Fyes present, sometimes median in position. The tarsi never end in suckers. The legs and palpi often have a few very lonp; bristles. Living upon plants.

Subfamily Biellinae. Palpi geniculate. Mandibles large. Cephalothorax with four long bristles above. Tarsus of leg I longer than tibia. Abomen usually broadest at the shoulders. Legs long and slender; hind coxae well separated from the anterfor pairs.

Subarnily Fapo:ljnae. Sult boljed. Palpi never geniculate. Beak small. Distal joint ol lex I shorter than the tibia. Eyes usually present. Palpi of four segments. 

Family Trombiojiae.

The last segment of each palpus forms a thumb which acts in opposition to the preceeding segment, the latter endirg in a claw, with few exceptions. Eyes usually present. Tarsi never terminate in suckers. Trunk divided into cephalothorax and abdomen.

Subfanily Caeculinae. Legs I and II with spirous processes. Integument Ieathery. Integumentary shields are present. Coxae contiguous, rectangy גar in form. Dorsum with a transterse furrow. The eyes are situated on pedicels. The ventral openings are large ani close togetrer, each being closed by means of valves SubfamiIy Erythraeinae. Paipi moving in a sagital plane. Legs I not ending in long hairs. Coxae contiguous, radiate. Legs slender: Bozy with few hairs. Tarsi never swollen. The body shows no conplete jivision between cephalothorax and abdomen and is short and broad. Two simple eyes. The legs terminate in two or three claws.

Subramily Tetrangchine. Body oval with few hairs and those mostly long. The cephalothorax and abdomen are separated by a furrow. Eyes two. Palpi short, ending in a claw. Mandibles with basal seginents uniter to form a plate and with the apical segments long and adapted for piercing plant tissues. Many of these nites spin.

Subfanily Trombidinae. A division exists between the cephalothorax ani the ahdomen. Cephalothorax very small. Mandibles chelate. Distal segment of leg I usually swolien. Body with many thick short hairs. Paini prominent, of five segments. Thumb 

large and usuaily clavate. Legs of seven segments and ending each in two claws.

Subfamily. Bhyncholophinae. Cephalothorax large and in the same plane with the abdomen. Eyes sessile. Palpi prominent of five segments. Mandibles styliform, slender and retradte. The body and legs are well clothed with hairs or bristles. The genital opening is situatiel botinep the hinc coxae.

\section{Family, Cheyletidae.}

Tiny mites, distinguished typically by enormous palpi attached to a distinct beak. Palpi of from three to five segments and rrequentIy with a minute movable subapical tubercle, which in some forms, is tipped wj.th one or two pectinate bristles. Body oval. Skin soft, nirirs few. Iegs usually short and of five segmerts. In sone species tho front legs are transformed into grasping organs. The mandibles are fitted for piercing tissues. Male aperture posterior to tine anus.

\section{Family Hydrachnidae.}

Aquatic. Body commonly short, nearly spherical with no division into cephalothorax and abdomen. Jegs are close together. Fyes present, ofter ciose to the median line. Integument soft. Palpi or four or fire semnertis. Juegs usually of seven segments; coxae often broad and entirely united to venter. The tarsi terminate broakly and usually have two claws.

Subfamily Halacarinae. Mouth parts carried on a distinct beak. No ventral suckers. Marine forms. 

Subfamily Hydrachninae. Mouth parts not carried on a beak. Suckers usialiy rresent near ferital openings. Fresh-water forms. 



\section{HABITS.}

Few arthropods have habits more interesting than those of the mites. The habits of all animals depend largely upon the food which they eat; so let us consider the kind of food that mites Iive upon. Mites are both herbivorous and carnivorous. The Oribatidue, according to Michael, who has studied that family very thoroughly, Iive largely upon fungi. The Gamasids are largeIy parasitjc ard can frequently be found on horses, cattle, moles, etc., as welI as on Hiris and irsfots. One genus of Gamasids, Uropode, is rrepuerty fond attached to beetles. They are fastened to the beetle by means of a pedicel, which is attached to the posterior pait or the mite. This pedicel was at first thought to be a process belonging to the mite, and one which could be

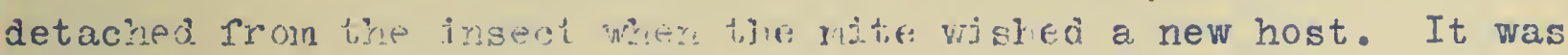
at length found, however, that the mite did not take the pediceI with it when if moved but that it detached itself from the pedicel.

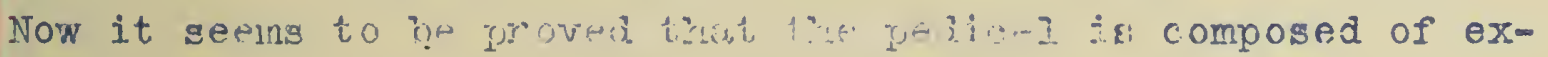
crement and trat by a new excretion the mite can detach itself from the peaicel. In the case of Uropoda it appears that they attach theinselves to tir fory of the insect purely for purposes of transportatior. One mill oft, foiri Coleaptera almost entirely covered with these Uropoda, which are shield-like in shape. I found a dead tumbiembug, the ventral parts of which were almost

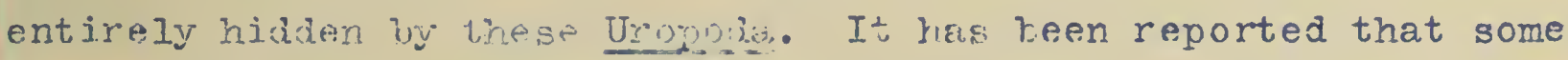
mites will kill other Acarina, especially the nymphs, though this has been deniex by many authorities. The Ixodidae, or ticks, are entirely parasitir; arit are farjiliar to most of us. They can 

be seen on the undersides of many vertebrates, as well as in the ears of dogs, câs, rahilts and raccoons. I have many of them taken from the ears of 3 , racisu. The food of Bdellidae is perhaps very similar to that of Oribatidae. The Trombiaidae are doubtless lare gely prytophagous.

Where are the haunts or the homes of the mites? Those which are parasitic have just, befn referred to, namely, the Ixodidae, Gamasidae and the nymphs of several other families: The most connon situations in which to find mites are under rocks, stones, boaris, logs, deaz leaves, straw, manure etc. Often you will finl then under the bark of trees, under moss, on the leaves of trees, or crawling over potted plants and under straw piles and de oris. Michael says that a favorite habitat for oribatidac is under mos3. I have pound them under rubbish and leaves, but seldom wnder moss, though I have found many other sorris in the latter situation. The Tetrarycil de rin re most often found crawling about on plants and flowers. The Trombidinae, I have often foldrl craming wp the trunks of eIm trees, especially on dry spring days. The Bielilike are easily gound in the fall or spring, simply by turning over boards or stones or dead leaves. Many of the non-parasjtic Gamasidae occur in a great variety of places. The most enunakyt supply that I have ever obtained was from beneaty a smali stack or deac weeds on the University farm. The Hydrachnidie, as the name signifies, are usually found on the water or near it.

The nites reiveat from the light as much as possible, and it is interesting lo note in conrection with tris subject that many of them are blind. Mites will also go towards sources of 

heat, and this fact is taken advantage of in the Berlese method of coliecting mitis in limet Gúchtity, as described elsewhere in tinis paper.

Some mites wil? "pejgy death" when touched, and other species will run away or else face an enemy. I often have noticed that the Iinopoles when attacked will whirl around, facing the disturber and will not resume tileir march until trey ire ro longer molested.

How do mites pass the winter? Most mites pass the winter in the adult stage; while others lay eggs, which hatch in the

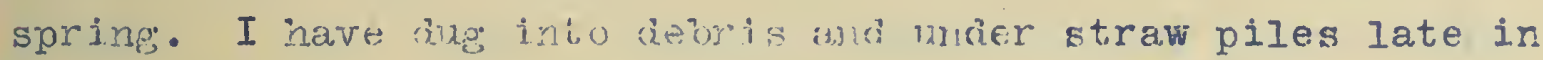

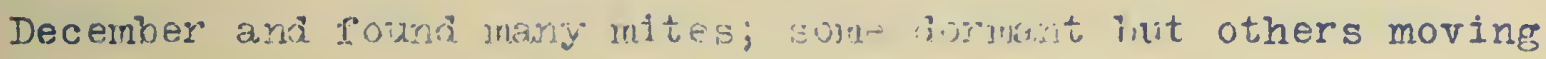
slowly about. I have gone out in January, however, and turned up boards, rocks, etc. and have found scarcely any mites. Presunably they go lom into the ground when the temperature falls below a certain point. I have turned up logs and boards in February, however, while the ground was still frozen and have found mites in consideroie quartity, where in January I could find none. By the sirst of March mites begin to be rarerous. In the laboratory I llave fompi not a few nymphs crawling over books, boxes, etc., ever in February.

The secondary sexual differences are often well marked in mites. As a ruie, tine forale is larger than the opposite sex, but not always, however. Trombiaium locustarium shows the secondary sexual characters very plainly. In this species the male is much smaller than the female and the body is pyriform in shape with a deep transverse furrow on the front of the dorsum; the female is larger, ans her voly is almost as broad behind as in 

front; furthermore, she has no transverse furrow. In the case of some Gamasids the male has a spur on the second pair of legs which is used in clasping the fentle. The bolies of the females are ofter grectiv jistender mith fegs. I have counted as many as a dozen egis in the body of a female of the family Bdellidae.

A great many kinds of mites will sometimes be found living together or apparenily so. Thus I have noticed no less than a dozen species mites winterine under the same board. 

IIFT HISTORY.

The life histories of mites vary greatly in the different families. Spective Eenerally, the life history of Acarina comprises four stages, namely, egg, larva, nymph and adult.

The eggs of Acarina have varicus forms. Those of Oribatidae are generally elifr,tical or cylindrical; sometimes they are slightly crescent shaped. The eggs have an outer membrane, which may be granulate or may be fashioned into irregular teeth. Often an inner meribrane is cormed around the embryo when the latter is developing. The number of eggs laid by one female varies greatly. I have counted as many as a dozen eggs in the body of one feunte of the funity Bifilidae and have found as many as twenty-five egణs in the body of one of the Trombidinae. In soine of the lower forms hundreds of eggs are laid by a single fernale. The eegs of most mites hatch soon after they are laid. It takes the larvae of some species several hours to hatch, though for nost species tile tine is much less. Michael has observed some of the Orinat fiae entray irom the eggs and describes the process as follows. When the embryo has become fully developed the ege splits along the inner membrane. The long legs of the larva are now folder apon the sides of the body and the long hairs of the back lie flat and are directed backward. First, the antorion part of the cepluizothorax emerges from the egg; then the first pair of leg; and next, the whole of the cephalothorax. Now the second legs gradually make their appearance. A long delay then takes nace, during which the various parts harden and 

assume their pernarert forr ard position. The hind legs remain in the shell until the last, assisting in the emergence of the mite by pushing against, the wall of the egg. As the different parts elitege, all tile appendages are kept in cortirual movement, a strange proceedure for tiluse slow and lazy creatures. The legs are worked in e.ll directions and the chelate mandibles, usually so djfficult to set, are protruded and retracted independent Iy and kept ceaselessir srapping.

The larvae of nearly all mites are hexanod. It is asserted

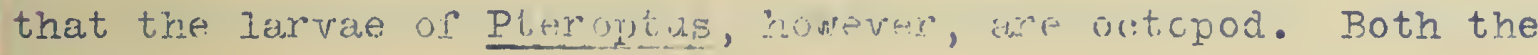

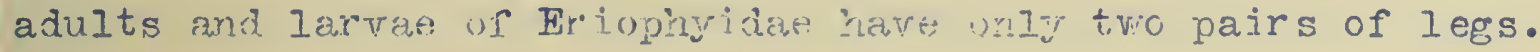
In most cases the larve bears but little resemblance to the adult. After emerging from the egg, the larvae feed a while and then pass into a restirg stage.

Duping infe ruphal reriod, the mite may moult once or twice. The nature of the internal changes during the nymphal stage has been tre shbiert of man ijsclission. Mégein in "Die Anatomie der Tyroglyphen" maintains t"at l: re is complete histolysis and complete histogeneis. Dr. Nalepa, however, as the result of a careful study of the development of Tricholactylus anonymus, denies the correctress of such a view. A. D. Michael has treated of this subject at corsicifable length, using several species, especially Notaspis bipilis and Notaspis lucorum, which are well adapted ror the roppos-, irec theig nymps have a smooth, colorless, and highly transparent ivitgintent through which the highly colored alimentary canal and its diverticula are very conspicuous. The observations of Mirhite? nay be summarised as follows: First, histolysig is itr from complete. In other words, there is not a complete breaking up of all the organs of the 

nymph prior to the formation of those of the adult, but some of the organs are identiceI in brin stages.

Second, where histolysis and histogenesis take place, they occur simultaneousiy.

Third, in the earlier stages of the transformation the contents of the numpha, skin shrink backward toward the posterior portion of tile animal, leaving the cuticula of the rostrum etc. empty; furthermore, the tissues of the legs withdraw into. the body cavity, leaving line cutichac of the legs empty.

Fourth, in tre later staps in trinsformation, the organs of the adult have again advanced toward the rostrum of the nymphal cutjcilla.

The entire process of transformation in the nymph requires usualiy several dijs or even several weeks. As was stated, the Iife histories are very different in the different families, the following being a gereral summary of the life-ristory:

Bdel11dae,- Ecos nearly spherical; larval and nymphal stages; both larva and nymph resemble the adult. Larva not parasitic.

Cheyletidae, -. Eggs denosited often in clusters. The larvae

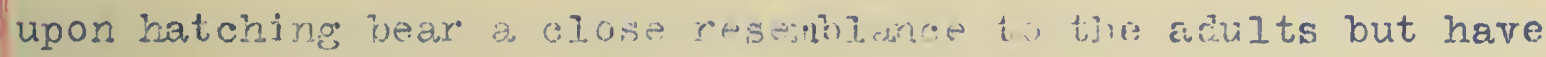
only six legss. Nyroh-like adult. Parthenogenesis occurs in some species.

Erythraenae and Tetranychinae, - Eggs oval, many heing produced by a single female. The larva and nymph both resemble the adult, excert in haring six legs.

Rhyncholophinae and Trombidinae,- Eggs oval, larva oval or circilar in nutine. Becoming attached usually to insects, thej feed upon those until the body becomes swolien, then arop to the 

ground and transform into adults.

Caeculidae,- Nothing is known as to the life history of this family.

Fydrachnidae,- The females lay their spherical eges on water-plants, stones etc. The deutovum condition of the egg occurs. Larva six-lezced. The larta upon hatching attaches itself to aquatic insects, and for this purpose is provided with sharp hooks at the tins of the short, stout palpi. The mouth parts of the larva, which are very srell, are inserted into the host. The boky becones swollen and the legs shrink, giving the creature the appearance of an elliptical egg. The nymph is formed in this sac-like boly, Irom which issues the adult mite.

Ixodidae,- The eggs of a single female may number ten thousand or more. As the eggs issue from the body they become coated with a viacous substance. The eggs are laid on the surface of the ground and hatch in a few days. The larva finds its host and attaches itseli. Aftur bocome distended with food, the larva arops off; ther, arter a few days the nymph issues from the old larval skin and hunts for a host. The nymph attaches itself to its host, becomes disteried with food; drops to the ground and moults, revealine tire adult.

Gamasiaae,- The egg hatches into a soft-skinned, six-legged Iarva, very different in appearance from the adult, with the excertion of pterorus and allied genera, which have eight legs on hatching. The larva moults and becomes an eight-legged nymph. The numphal stage is orten the longest and most active period of the Iife history. After a series of moults the adult stage is reached. The following names have been given to the different 

nymphs in the order of their occurrence; protonymph, deutonymph, and tritonymph. During their nymphal stages, many species are attached to various insects for the purpose of transportation. Oribatidae,- The eggs are sometimes deposited, and sometimes ripen in the body of the parent mite, the mother dying and her shell remlining as a potiction $f \mathrm{cr}$ the eggs. The larva, however, has a soft skin. When the nymph is about to become an imago it seeks some sheltered spot and firmly fixes its legs to some object. In about ten days the imago appears.

Tarsoneminae, - The eggs develop within the body of the female, which causes the abiomen of a pregnant female to swell to an enormous size. Indiviluals develop within the mother and issue forth as sexually mature males and females.

Tyroglyphinae,- The eggs are large. The young on hatching are six-iegfen, hut upon moultirg, two more legs appear. From now on the process of development to adult the condition is simple. There may be, howeror, a "Hypopus" stage. The Hypopus is tery ilferert in dpearico som the adult. It has sucking disks by means of which it attaches itself to insects or other creatures for the rirpose of transportation. On finding a suitable situation, it noults into an octopod nymph, which develops into the adult mite.

Analgesinee,- Eggs large and elongate. Larva six- or fourlegged. Some maintain that the six-legged form is a nymph. The nymph has the general form of an adult, but lacks genital or gans, however. In some species the Hypopal condition develops from a nymph. The adult male develops directly from a nymph, but the female has a stage intermediate between the nymph and the adult. 

Sarcoptidae,- The eggs are laid in the skin of animals. The new I hatched larva is six-legged, the last legs ending each in a long bristle. Sorne of the species moult four times before maturity.

Friophyidae, - The eggs are laid on the surfaces of leaves. The young on energing from the egg are helpless, being without tarsal appendages, but these soon appear, at the first moult. Moults occur before the adult stages are reached.

Demolecide, - The egg is fusiform. The larva is hexapod, moults and becomes octopod. After tvo more moults maturity is attaines. The nimpis greatly resemble the adults. 



\section{ANATOMY.}

In Acarina, two regions, at most, are distinguishable: the thorax and abdomen, though frequently these two regions unite to form one. The appendages consist of four pairs of legs, the mandibles and the palni. The body is often thickly clothed with hairs or bristles, though in some species it is naked.

The mouth parts consist of the manuibles and the palpi. To these are sumetinf:s added other structures, as the lip, hypopharymx etc. The mandibles have usually two segments, of about equal length. often the mandibles are chelate, the last segment opposing the penultinate one. The mandibles, furthermore, may be long and styliform, for the purpose of piercing. In certain Gamaridae the mandibles can be entirely withdrawn into the cephalothorax. The tips of the mandibles are always heavily chitized.

The palpi consist of from three to five segments. In some species the pali are free; in others they are almost obsolete, being unjted with the rostrum. The palpi are often slender, ending in two or more large bristles, as in Bdellinae, for example. In this group they are exceptional in being geniculate. In many instances the palpi end each in a claw or a thumb, or both In the Trombidiae the last seement of the palpus forms a thumb, which acts in opposition to the penultimate segment. In oribatidae, Sarcoptidae, and Tetranychinae the palpi are rather short and are clothed with only a few short hairs. In Chelatidae, however, the palpi are very large with an enormous base and with special terminal modifications, consisting of a movable papilla 

near the ayex, and two or more pectinate bristles. In other mites the palpi end each in a single claw or hook, and have several stout spines. The mouth narts vary greatly in size but are very prominent in Gamasidae, Trombididas, Bdellidae and Chelatidae. In Oribatidae, however, they are very small and often obscure. The cephaiothorax, when distinct from the abomen, varies greatly in its relative size. In Bdellidae it is almost as large as the abionen out in Trombiaidae it is very small, often less than one tertir tre size of the dubnen. The cephalctrorax is prominent in Gamasidae, Oribatidae and Tetranychidae, and in these families is separated sharply from the abdomen. Eyes are present usually but not always; when present they are situated sometimes on the sides and sometimes on the median line. In Trombidinae they are situated on a stalk or "pedicel". In Oribatidae are found several peculiar structures, for example, the "pseudostigmata,"-small cylindrical, chitinous projections on the sides of the dorsai surface. Feck pseudiostigma has a "pseudostigmatic organ" projecting from its distal end. This organ varieg in shape: it may be broad and stout, spindle shaped, styliform or pectinate. On each side of the cephalothorax in Oribatidae is a chitinous shelf-like expansion termed a "lanella"; below and in front of this is a slender chi inous projection known as a "tectopod". The front of the cephalothorax on the dorsal side often forms a "rostrum", and the region behind the rostrum is known as the "dorso vertex".

The abdomen is usually, though not always, the largest diFisjon of the body and bears but few external structures. On the ventral side, however, are situated the genital openings and 

the ams, though in a few species the arus opens dorsally. The anal and genital openings in the case of the oribatidae are provided with chitinous, folding valves which when clesed completely cut off access to the exterior. On the ventral side of the abacmen in many of the mites, is a large ventral plate forming a part of the exoskeleton; orten, also, an anal and a genital plate. On the dorsal side of the abdomen there is usually a large plate termed the "dorsum." In oribatidae there is a prominent chitinous wing-like expansion on edch give of the abdomen termed the "pteromorpha". The abdomen is frequently oval in form, but often globular, and in the genus Nothrus, rectangular. In Eriophydae the abionen is vermiform with many segments.

The legs of Acarina vary greatly in form. Excepting in Eriophyidae, there are four pairs of legs in the adult. In the nymph there are usually three yoirs. The logs in most families are stout. One, two or three claws are present at the distal end of the last segment. The number of segments in each leg varies from five to seven. In some instances the second pair of legs are much enlarged and are modified for the purpose of grasping. The front legs are generally more slender and sometimes much smaller than the others, being orten used for tactile purposes. Such mites as are parasitic and such as adhere to other animals for the purpose of transportation, usually have legs that are adapted for clinging to their host.

Certain mites have always attracted more or less attention on account of their vivid colors. Thus the Bdellidae and Tetranychilae are usialiy bright red, the term "red spiders" being applied to members of the latter family. The oribatidae are as 

a rule either black or else dark brown, though there are several excertions to this rule. Gamasidae are usually brown, but sometimes blackish, yellowish, pinkish or even greenish in hue. Most of the smaller forms, as Eriophydae, are inconspicuous as regards color. The Hydrachnidae are as a rule very highly colored, being red, scarlet, yellow, yellowish green etc., with spots of black or brown.

The texture of the integument varies greatly in the different forms. In Sarcoptidae and Eriophyidae the integument is rather soft. In Gamasidae and Ixodidae, however, it is leathery and tough, and sometimes very hard. The oribatidae have a heavily chitinized integument, and on account of this were long known as "beetle mites." The body of mites is usually clothed wi.th hairs, which vary greatly in size, form and number. Often the hairs are small and single. Some of the Trombidinae, however, have feathery hairs and others clavate hairs. Pectinate bristles are frequent on the anterior part of the body and legs and in some genera over the entire surface of the body. The hairs are so thick in the case of some Trombidinae as to almost completely hide the integument, though certain Oribatidae, on the cther hand, are hairless. The study of the internal anatomy of Acarira is as difficult as it is interesting.

The following list of investigators and their works is very helpful for a study of the internal anatomy of Acarina. Fenking, $\mathrm{H}$.

1882--"Beiträge zur Anatomie, Entricklungsgesichichte und Biologie von Trombidium fuliginosum Herm." Zeits. für Wissen. Zool. rol. 37 pp. 553-663,3 pl. Review 

of same Jour. Roy. Mierv. Soc. Ser. 2, vol. 3, 1883. pp. $210-211$.

Mégain, P.

1876-.."Monographie de la Famille des Gamasidés." Jour. de Ia Anat. et Phys. 1876, pp. 288-336.

Michae I, A. I.

1883--"British Oribatidae." Ray Soc. Iondon, vol. I, Chap. 10, pp. 142-130, pIs. D.E.F.G.

1883--"Observations on the Anatomy of the Oribatidae."

Jour. Ray. Mic. Soc. Ser. 3, vol. 3, 1883, pp. 1-22.

1889--"Observations on the Special Internal Anatomy of Uropoda Krameri" Jour. Ray. Mic. Soc. 1889, p. I.

1893--"Variations in Interna.I Anatomy of Gamasinae" Review

in Jour. Ray. Mic. Soc. 1893, pp. 736.

1894--"Notes on the Uropodinae" Jour. Ray. Micro. Soc. 1894, จ0.. 8, pr. 315-317.

1895--"Anatomy of Thyas petrophilus" Proc. Zool. Soc. 1895, pp. 174-209. (3 pls.) Rev. in Jour. Royal Micro. Soc. $1896, \mathrm{p} \cdot 60$.

1895--"The Form and Proportions of the Brain in the oribatidae and in some other Acarina." Jour. Ray. Micro. Soc. 1895, pp. 274-281, pl. 6. 1897--"Resume of the Anatomy of Bdella" Jour. Ray. Micro. Soc. 1887, n. 2, pn. 103-106.

Nicolet, M. H.

"Acariens des Environs de Paris" Chan. 4, pp. 410$415, \mathrm{pls} .1$ and 2 . 



\section{DESCRIPTION OF SPECIFS.}

\section{FARIJY SARCOPTIDAE.}

Subfanily Tyroglychinae.

Tyrogiynhus pryyloxerae.

1874. C. V. Riley, Sixth Ann. Rept. Nox, and Ben. Insects of ro. p. 52 .

Average measurements,--Length, $70 \mathrm{~mm}$; breaath, $35 \mathrm{~mm}$; length of first par of legs, $30 \mathrm{~mm}$.; second pair, $30 \mathrm{~mm}$; third pair, $34 \mathrm{~mm}$; fourth pair, $36 \mathrm{~mm}$.

The mandjoles are short and scissor-like, one third as broad as long.

The palrit are srik?.

The cerghifothoras is ahout one fourth as long as the body. The boily is oval in shape, about two thirds as broad as long. There are several long hairs on the dorsum of the abdomen, they are about as long as the ho

The posterior pixir of legs if longer than the rest. The tibia of each pair of legs has a long bristle at its distal end; tarsus with single claw; claw one third as thick as long.

Color of mite is a light yellowish green.

The integument is smooth and soft.

Distribution, --

United States, described by C. V. Riley, Missouri. United states, collecteri by Mr. West, Urbana, Illinois. This mite lives on the roots of plants and in its hypopal stage is attached to insects. 

FAMIIY GAMASIDAE.

Subfarnily Uropodinae.

Alliba n.sp.(?) .

Average measurements, - - Length, $.66 \mathrm{~mm}$; breadth, $.56 \mathrm{~mm}$;

length of first pair of legs, $.12 \mathrm{~mm}$; second pair, $.12 \mathrm{~mm}$; third pair, .24 me; fourth wir, .26 mm.

The boly is almost circular in shape, but a little longer than broad. The posterior pair of legs are situated about two thirds the distance from enterior to the posterior end of the body.

The anterior puir w Ifgs jo cmall, not extending beyond the margin of the body; the other three pairs are subequal and extond about half their lergth beyond the margin of the body. The coxa

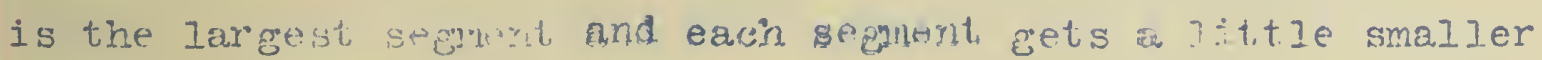
than the preceing as we cunt aut from the body. The legs have a rew very stout, surt, sherp r.rigtles about one third as broad as Iong; claws are small and curved with a large sucker between then.

Color of mile is brown.

The skin is thick and hard, body with a very thick shelllike cuticle; cutjole on lege not so thick; surface smooth.

Distribution, --

Unitied states, collected by myself, Urbana, Illinois. This mite is parasitic on coleretien. 

Subfarnily Grmasinae.

Folostasjis n.sp.(?), pl.l, fig.l.

Average measurements,--Length, $1.20 \mathrm{~mm}$; breadth, $80 \mathrm{~mm}$.; length of palpi,.60 mm.; first pair of legs, I.20 mm.; second pair, $1.08 \mathrm{mn}$; third pair, 1.10 rw.; fourth pair, $1.60 \mathrm{~mm}$.

The mandibles extend almost to the end of the palpi; one finger ends in a straight point, the other is semicircular; there is no spur or flagelium. Cusps of hypostome one half as long as mandinles.

The perui are tuvo rifins as long as leg I; anti penultimate segnent twice is long as penultimate; distal segment very short,

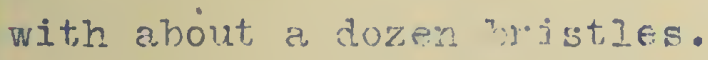

The body is oval, three fifths as broad as long; two straight

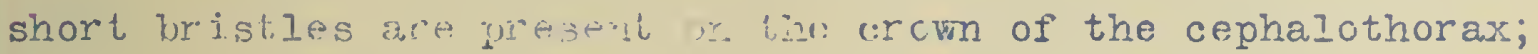
two pairs of short equal clavate bristies on the shoulders; two pairs of clavili "risties on the dorsal, posterior margin of the abdomen; ana.l plat k roaner than long and larger than sternal plate, which is of uniform length and breadth.

The anteriur pair of legs is a little longer than the body; posterior pair congiderinly Iorger; coxa of leg I, twice as long as broad; segment two, two thirds as long as coxa, segment threc very sinall, one third as long as two, and ahout three fifths as broal as two; tivia dnd tarsus whequal in length, both well clothed with hairs; tarsus ends in about a dozen and a half bristles, two of which ale somewhat longer than the rest. The bristies of the nind legs are esrejuig stout, a long bristie is situated at dooll ine midole of the tarsus on the inner side. 

Light brown in color.

The skin is thick but brittle; surface rough; dermis of hind legs especialiy trick.

Distrirution, - -

United States, collected by myself, Urbana, Illinois.

\section{Seius n.sp.(?)}

Average measurements,..-length, $.60 \mathrm{~mm}$; breadth, $.50 \mathrm{~mm}$;

Iength of first pair ư Iegs, $40 \mathrm{~mm}$; second pair, $.32 \mathrm{~mm}$; third pair, $.30 \mathrm{~mm}$; fourth pair, $.40 \mathrm{~mm}$.

The mandibles are very small, they do not extend in front of the margin of rostrum, consist of a long pair of pinchers with curved tips.

The palpi are two thirds as long as legs I; segment two, the longest, being thref times as long as broad; segment three, three fourths as long is two; swent four, three fourths as long as three; aistal segment very short, being hardly one haIf as long as the penultiritit, and is narrower than the other segments and bears severul short irist. Ies at the end; segments two and three each have a short bristle on their median sides.

The body is oral, two thirds as broad as long, and has a very few short hairs; abut five clavate bristles on the sjodes of the hody towards the anterior end, they are curved towards the median plane and point backwards.

The anterior pair of legs is as long as the body, the other legs are about two thirds as long. The front pair of legs are quite crooked, being almost in an $S$ shape. Segments one and two

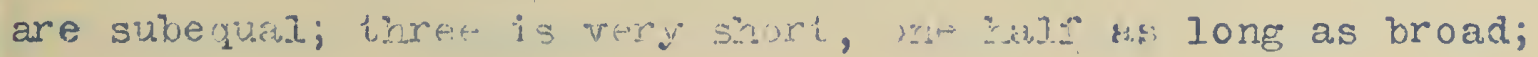
four, five, and six «re subequal, each being about twice as long 

as two; the tarsus is a little longer than the tibia and ends in two small cledw; the tex sus hets reny short hairg.

The mite is a uniform light brown in color.

The skin is tough and hard, surface almost smooth.

Distribution, - -

United states, collected by myself, Galesburg, Illinois. United States, collected by myself, Urbana, IIIinois.

\section{Se1us hjisutus.}

1900, A. Berlese, GIi Acari Agrarii, p. 41.

Averag゙e measurerents, --Iength, $50 \mathrm{~mm}$; breadth, $28 \mathrm{~mm}$;

length of palpi,. .I\% mm.; first pair of legs,.52 mm.; second pair, $.40 \mathrm{~mm}$; thira pair, $.40 \mathrm{~mm}$; fourth pair, .52 mm.

The mandibles are small and short.

The palpi are ahout one third as long again as segment three of leg I; segment two is as broad as long; segment three is twice as long as two; segrerts four and five subequal; segment five has a few snall brist.Ies on the end; palpi about as broad at the end as at the base.

The bo iv is about three fifths as broad as long, almost rectangular and his mary larøe, long, curved bristles; there is a

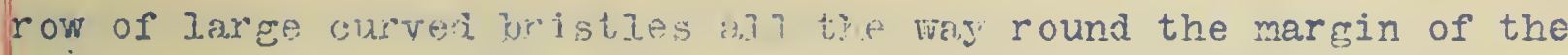
body; the bristles are longest at the posterior margin where there are ford about the smite Irygth as the palpi; there is a pair of thick bristies on lif stolinars wich project at about right angles to the surface; just behind these the bristles are very short and much curved, the first pair being about one half as Iong as the shovider bristies.

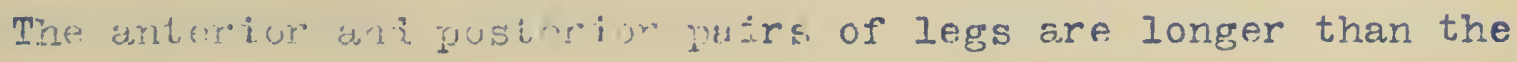



body; the other two pair are about as long as the body. The tarsus of leg $I$ is twice w long as the tibia; the coxa is a little longer than segnent two; segnert three is very small being about one half as long as two; segment four is about as long as the caxa and segment two taken together; segments five and six subcqual, each has two roirs of shrt, stout bristles; all the legs have short, stout bristles.

Specimens are a light brown in color; the legs are lighter than the bosy.

The skin is very tifck and hard; the body is covered with pits making the surface wery irregular.

Distribution, .-

United States, collected by myself, Urbana, Illinois. Found under dead leaves and under trash.

\section{FANIIY ORIBATIDAE.}

\section{Subfamily Hoplrderminae.}

$$
\text { phthiracarus n.sp. ,pl.4, fig.2. }
$$

Average measurements, - - length, .70 mm.; thickness, .36 mm.; length of first pair if Ieg, $.24 \mathrm{~mm}$; second pair, $20 \mathrm{~mm}$; third pair, .20 mm•; fourih ajr, $.20 \mathrm{~mm}$.

The ceplalothorax is twice as long as thick; mandibles very prominent and stout and can be retracted so that they are invisible; psexlostignatjc organ clavate; a pair of hairs about two thirds as long as the ceplnlothorax is situated at the posterior margin of the same; in front of this pair is a similar pair about two thiras as Iong; the rostral hairs are about two thirds as long as this pair. 

The abdomen is akout three fifths as thick, as long and is very narrow; on the dorsum are five pairs of long bristles of equal length; on the posterior ventral surface are four pairs of short, straight oristles; the abdomen is, curved with small pits, rounded behind and trurcated in front.

The legs are subequal; as long as cephalothorax; claws tridactyle, half as long as tarsus; the tarsus is twice as long as the tibia and has many long hairs; the tarsus of leg I has very long tactile bristle, halr as long again as the tarsus itself; the tibia and genual are subequal.

The body is a dark brown; the legs are much lighter.

The integunent is hard and resistant and well chitinized; the interument or legs not so thick as that of the body. The body is covered with small pits.

\section{Distribution,--}

United States, collected by myself, Danville, Illinois. Found under Iogs and boards.

\section{Subfanily Orinatinae.}

\section{Oribata lu casi Nicolet}

1855, M. H. Nicolet, Arch. Mus, Paris, Vol. 7, p. 432, pl. 4,fig.2. 1884, A. D. Michael, British Orjhatidae,vol. 1,p. 262, pl.1I,fig. $1-5$.

1898, A. D. Michael, Das Tier., Iief. 3, p. 22. 1901, I. Tragardh, Arachniden aus Agypten und dem Sudan p. 122. Average neasurements, .- length, $60 \mathrm{~mm}$; breadth, $40 \mathrm{~mm}$; length of first pair of legs, $32 \mathrm{~mm}$; second pair, $24 \mathrm{~mm}$.; third pair, $24 \mathrm{~mm}$; fourth pair, $30 \mathrm{~mm}$.

The cephalothorax is pyramidal in shape; lamellae short 

with very small cusps; two poirs of rostral hairs, both pairs denticulate, the anterior pair is shortest and projects almost directly forwaris but curved slightly towards the median plane. The hind pair is stratght and is directed forwards. The interlaruellar hairs are as long as the posterior rostral hairs, they are denticulate shlo slichtly curved away from the median plane. The pseudostjenatic ngan is clavate and is as long as the femur. The abdomen is oblong; the pteromorphae extending beyond the margin or the dolomen ard cephalothorax; pteromorphae truncated. The abdomen has a few very minute hairs; the anal plates are twice as long as brodk, ant are approximate to the posterior margin of the ventral plate ari tive its length behind the genital plates. The genitial plates are one half as large as the anal plates. The ventral plate is of medium size.

The legs are short and stout, subequal in length. The first pair is two thirds as long as the body. The tarsus, femur and tibia are aIl of about the same length. The femur is over one half as thick is long. The genual is very small being about one third as long as the femur. The tibia is broad and square at its distal enci and i, injs end carries a long bristle which is twice as long as the segment itsenf. There is a similar bristle situatod at the same place on the other legs.

The color of the abdomen is a very dark brown, legs lighter. The anterior part of tine duamen and the posterior part of the cephalothorax is black.

The skin is thick and very resistant; surface smooth. Distribution, -Az geria Frarce, reported by M. H. Nicolet, commonly distributed. 

England, reported by A. D. Michael, generally distributed. United States, collected by myself, Urbana, Illinois. Egypt, collected by Swedish Zool. Exp. I. A. Tagerskidd. Found under boards and in rubbish.

$$
\text { Oribata n.sp., pl.3.fig.3. }
$$

Average measurements, - - length, $.80 \mathrm{~mm}$; breadth, $.50 \mathrm{~mm}$; length of rirgt pair of legs, $.36 \mathrm{~mm}$.; second pair, $.32 \mathrm{~mm}$.; third pair, $.32 \mathrm{~mm}$; fourth pair, $.34 \mathrm{~mm}$.

Ianella absent; rostrum thick with rounded anterior end; rostral halrs curved aric pectinate. The tectopod is blade-like and two thiris as long as the rostrum. The pseudo-stigmatic organ is clavate and pectinated. It is about as long as the tarsus of leg I. The interlanljar hairs wre thick and pectinated.

The abdomen is slightly pyriform and hairless. The pteromorphae are sharp pointed and extend forwards almost to the tip of the rostrum. The anal and genital openings are far apart. There is an anal process about half as long as thick also a genital process abuut two tihjods as large as the anal process.

The females have a long segmented ovipositor which is thrust out upon killine vij.th hot water. It is about as long as the body and is rorked the end.

The first pair of legs is twice as long as the cephalothorax. The tarsus is the longest segment, it bears a large plumose hair about one third the distance rrom the proximal end of the segmont. The tibia is much thicker than the tarsus and is globose at its distal end; it is about two thirds as long as the tarsus. The gerual is as Iong as the tibia, but only about half as thici. The femur is large; the coxa small. The legs are subequal in 

Iength: fourtin pair Iongest; the second pair has a very thick fernura.

The boity is a dark brown, the legs are ligiter.

Integument smooth and polished on the abionen; the cephalothorax is a litile, rough. The integument is well chitinized, and exceptionally hard.

Distribution, --

United. States, collected by myself, Urbana, IIIinois.

\section{Subfanily Apterog isterinae.}

Damaeus sufflexus Michael.

1885, A. D. Michael, Jour. Roy. Micro. Soc., ser. 2, vol. 5, p.394.

1888, A. D. Michae 1,British Oribatidae, v01.2, p.415,pl.34, figs. 9, 10 .

1895, A. Berlest, (Belba sufflexa).A. M. S., fasc. 74, nr. 4. 1898, A. D. Michael, Oribatidae, Das Tier., Lief. 3, D. 58. The rostrum is of medium length and slightly pointed at the apex. Lamella absent. There are no lamellar hairs, but there is a pair of similar stout, slightly curved hairs. Pseudostigmata long, projectirg, nedrly uprigint, cylindrical in shape. The pseudostigmatic organs are very long, about as long as the cephalathorax, rod-like in shape. The general shape of the cephalothorax is siorectanglar, axcepting the rostrum belng a little wider than Iong. There is a rather large boss under the pseudostigmata.

The abdomen is globular; progaster rounded. The notogaster bears a row of about five short, stout, slightly curved hairs on each side, wich project slightly over the margin of the abdomen. 

The ventral plate is smal1. The anal and genital plates are of almost exactiy the same size and shape viti a very smalj. margin betwer. tiner.

The legs are rather long, of medium thickness, and weII represent the type Damaeus. The femur of leg I is twice as Iong as the genual ayr bears two lares bristles on the outer distal margin. The genual is two thirds the length of the tibia; the tibia is two tiniris tine Iength of the tarsus. The tarsus bears a very thick oristie on tine proximal, outer margin and tapers toward the distal end.

The color of the body is Iight brown; the legs are almost ye110w.

The cephalothorax is dull; integument slightly roligh; abdomen smooth, not polished.

Distribution, --

England, collected by E. Bostock at stone, Staffordshire. Ingland, coliected by A. D. Michael at Keswick, Cumberland. Italy, collected by A. Berlese.

United States, collected by T. W. Folsom at Dedham, Mass.

In England it was found only in moss on the ground. In America the single specimen was found under a rotten $10 \mathrm{~g}$.

\section{Damaeus ecticola MichaeI.}

1888, A. D. Michael, Britisi Oribatidae, vol. 2, p.416, pl. 35. 1893, I. KarpeIles, (Belba mirabilis) Math. naturw. Ber. Ungarn., vol. $2, n .85$.

1895, A. Berlese, A. M. S., fasc. 77, nr. 9.

1898, A. D. Michael, Das Tier., Tief. 3, p. 58. 

Average measurements, - - length, $.54 \mathrm{~mm}$; breadth, $.42 \mathrm{~mm} \bullet$;

length of first pair of legs, $.56 \mathrm{~mm}$; second pair, $.44 \mathrm{~mm}$; third pair, $.60 \mathrm{~mm}$; fourth pair, $.90 \mathrm{~mm}$.

The cephalothorax is broader than long; rostrum of medium length and rounded in front; lamellae absent; rostral hairs stout and curved very much lowards the median plane; palpi of five segmonts and in the shape of a figure tinree, pointed towards the distal end and ending in two very short bristles; basal segment much the longest. The gecond segment of the palpus is one third as long as segment I, three and one half as long as segment II, four and rive suivequel. The pseudostigmatic organ is setiform, as long as remur of leg $I$, it is denticulate.

The abdomen is globular, broader than long. It has about eight short, tinici, curved, denticulate, equal bristles; ventral plate of medium size; anal plates situated about their length from dorsal margin of abdomen, and one half their length from the genital plates; they are a little longer and slightly narrower than the genital plates.

The legs are very long; hind pair much the longest. The first pair of legs are half again as long as the body. The femur and tarsus are of almost the same length; femur curved at its proximal end, distal end clavate. The genual is small and short, scarcely one tinirdas long as femur; tibia twice as long as genual, tarsus is almost globular at its proximal end. The legs possess many stout, cirved, lenticulate bristles. All the segmonts except the genual are clavate.

A uniform rather dark brown color.

The skin is very thick and tough; not polished and not smooth, covered on the abdomen with many minute depressions. 

Distribution, --

Fingland, collected by A. D. Michael in Warwicksirire. Italy, reported by A. Berlese.

United States, collected by myself, Urbana, IIIinois.

In England the specimens were collected from the thatch of an old cottage which was being pulled down. I collected specimens from inder bogrds and rubbish. Specimens have been collectad from moss.

\section{Liacarus n.sp. .}

Average measurements,--length, $50 \mathrm{~mm}$; breadth, $.32 \mathrm{~mm}$;

length of ijst pair of legs,.26 mm.; second pair,.22mm.; third pair, .20 mm.; fourth pair, .24 inm.

The cephalothorax is rather short; lamellae one third as Iong as cephalothorax; rostrum thick but somewhat pointed; rostral hairs long, curved slightly towards the median line, pectinated. The palpi are large, have four segments, proxinal and distal segment each with a curved bristle; pseudostigmata small; pseudostigratic orgun as long as femur of leg $I$, narrow at the base, clavate in shape but pointed at the end. The inter lamellar nairs are twice as long as the pseudostigmatic organ.

The abdoinen is zinost globose. The progaster curves convexIy down to meet the cephalothorax. There are a few very short hairs on the ablomen; ventral plate large; anal plates situated approximate to dorsal margin of abjomen. The anal plates are situated approximate to the dorsal margin of abdomen; they are over twice os lar ge as the genital plates. Genital plates situated three times their length in front of the anal plates. The legs are subequal in length; in pair I the femur and 

tarsus are of alnost tine sane length. The tibia is four fifths as lonf as the femur; the genual is one half as long as the tibia. There are no Iorgo bristles on the first pair of legs, tibia of leg III has a bristie is long as the segment itself; legs III and IV each have a similar bristle.

The mite is of aniform brown color.

The integument is smooth and somewhat delicate in texture. Distribution, --

United States, collected by myself, Urbana, Illinois.

Notaspis aequalis. Iichael

1890, A. D. Michael, Proc. Zool. Soc. Iond., x.. 37, fig. 5. 1898, A. D. Michael, Das Tier., Iief. 3, p. 46. Average measur ments,--length, $.40 \mathrm{~mm}$; breadth, $26 \mathrm{~mm}$. The cepariothorax is broad; ratiner pointed in front; lamella broad, cusps of lamella with a long point; rostrum broad; rostral hairs as long as femur of leg I and slightly curved towards the median Iine, nates denticulate; interlamellar hairs Iong, denticulate, almost straight and slightly converging towards the median plene; pseudoștignatic organ short and thick, club shaped.

The abdomen is globose. The progaster has a boss on each side which bears a large bristle which is curved and points slight ly backwards. The akomer has a very few short hairs; ventral plate large; anal plates almost approximate to the marein of abdomon; they are half as large again as the genital plates which are situated at, $\Rightarrow$ distance equal to twice the length of the anal plates in front of the same.

The posterior pair of legs is longest; they are about as Iong as the ahioinen. 

The anterior pair is three fourths as long as the posterior pair. The femur and tarsus of the first pair are subequal in length; the fernur is two thirds as broad as long; the genual is one thira as long as the femur; the tibia is as long as the tarsus and three times as broad at the distal end as at the proximal end. There is a long bribtie on bine tibia of leg I, as long as the seginent itself. A similar but somewhat shorter bristle is present on the anterior edge of the femur of leg III and the tibia of leg IV.

The nite is a uniform brown in color.

The integument is smooth and moderately tough.

Distribution,--

Algeria.

United States, collected by myself, Urbana, Illinois. Found unier bourds and rubbish.

$$
\text { Notaspis n. sp. . pl.4, fig.l. }
$$

Average measurements,--length, $.50 \mathrm{~mm}$; breadth, $.28 \mathrm{~mm}$;

length of first pair of Iegs $.30 \mathrm{~mm}$; second pair, $.32 \mathrm{~mm}$; third. pair, $.36 \mathrm{~mm}$. ; fourth pair, $.46 \mathrm{~mm}$.

The rostrum is broad; lamellae small and truncated, about one third ine lengtin of the cepialothorax. Translamella absent; pseudostigmata very small and on the dorsolatteral part of the cephalothorax; pseulostigmatic organ rather slender, pectinated and slightly club-shaped. The general shape of the cephalothorax is that of an irosceles triangle with the base of the cephalothorax corresponing to the base of the triangle.

The abdonen is slightly oval and tapers towards the posterior end. The progaster curves convexly down to meet the cepha- 

lothorax. The abdomen has about twelve short slightly curved bris tles; ventral plate large; anal plates are large and are situated approximate to the dorsal margin of the abdomen and about twice their length from the genital plates, which are anout three fifths as large as the anal plates and are situated very near the anterior margin of the ventral plate.

The first pair of legs are almost as long as the body and each succeeding pair is longer than the preceeding. The tarsus of the first pair of legs is stout and tapering. The coxa of the third.pair of legs are globular and bear a large bristle each on the anterior margin.

The tibia of the fourth pair of legs bears on the anterior distal maxgin a Iarge brjstile as long as the tibia itself. The genual of all the legs is very short; in the third leg it is about one third the iength of the tibia.

The color of the mite is a light yellowish brown.

The texture is slightly rough, unpolished; the dorsum of the abdomen is rougher than the rest of the body.

Distribution, --

United States, collected by myself, Urbana, Illinois. Found under boards and debris.

\section{FAMIIY BDELIIDAE.}

Subfamily Bdellinae.

Bdella peregrina Banks, pl.5, fig.l.

1894, N. Banks, Trans. Amer. Entom. Soc., vol.21,p. 219. 1895, N. Banks, Ann. N. Y. Acad. Sci., vol. 8, p. 433. Average length, $1.40 \mathrm{~mm}$; breadth, .66 mm.; length of man- 

dibles, $.44 \mathrm{~mm}$; palpi, $.62 \mathrm{~mm}$; first pair of legs, $.80 \mathrm{~mm}$; second pair, 1.mm.; third pair, $1.10 \mathrm{~mm}$; fourth pair, $1.30 \mathrm{~mm}$.

The manibies are stout, about as long as the cephalothorax. A pair o1 large bristies is present about one third the distance from the end of each mandible.

The palpi are as long as the mandibles; second segment is the Iongest, the istal segment is almost as long as the second; segments three plus four are less than half as long as the distal segnent. At the end of the distal segmentare two bristles of equal length, heing allout ino linds the length of the distal segment. Segments two and five each have about six small bristles The cephalotiorax is about as long as broad and slightly concave; anieriorly it is drawn out to form a neck. On each side at the posterior dorsal region are three eyes; the middle one is smaller than the others. There are two paranedian, dorsal bristles directed forwards and ahout as long as femur of leg I. There are three other small bristles on each side of cephalothorax.

The abdonen is viblong, about half as long again as cephalothorax. Anteriorly on each side are two moderately large bristlcs, the arterior being the longer. Posteriorly there are two pairs or shrort, stout, curved bristles; the more median pair being about half as long as the other pair.

The anterior part of the abdomen is about half as broad again as the posterior part.

The posterior pair of legs is longest. In the first pair the tarsus is the longest segment, being a little longer than the femur. It carries iz stout, short bristle in front near the distal end. The tibia is about half as long as the tarsus; segments 

three and four are of about equal length, each being ahout two thirds ds Iong as the tibia. The first and second pairs of legs, subequal. The third pair is a little longer and has one bristlo a little laregre thar the rest, on the distal end of the tibia.

The general color is orange red, with large black areas; one large area on the median line of cephalothorax. There are three large spots on each side of the abdomen; legs and palpi much paler, almost colorless; neck very pale; integument rough. Distribution, --

United States, reported by N. Banks, Sea Cliff, IN. Y. United States, collected by Baker, Fort Collins, Colorado. United states, collected by myself, Urbana, IIIinois.

All the specimens reported have been found under boards and ruvoish.

Boielia silvaticus Kramer.

1895, Sig. Thor (scirus s.) Norwegische Bdellidae II, Zool. Anz.., BR. 29, nr. 7, np. 204-205.

Average measurements,--length $1.04 \mathrm{~mm}$; breadth, $.58 \mathrm{~mm}$; lengtin of mandibles, $.36 \mathrm{~mm}$; of palpi, .54 mm.; first pair of legs, .72 mm.; second pair, .68 mm.; third pair, .78 mm.; fourth pair, .82. $\mathrm{mm}$.

The manilinles are thick at the base and taper to a fine point at the apex; they are two thirds as long as cephalothorax; two bristifes erre situated on each side close to the base, the antorior is the loyegr; bifye is one bristle on each side on third the distance from the tip of the mandibles.

The palpi are half as long again as the mandibles; the second soznent is lorgest, it is almost as long as the mandibles; 

third segnent is one half as long as the fourth, both together almost as long as the distal segment.

The distal segment bears two long bristles at the tip; the outer is the longer, being almost as long as the mandibles; two rather large, but much smaller bristles on the sides of the segment.

The cerhalotherax comes down rapialy in front to form a short neck; sicies wryex. There is a pair of long bristles on the cephalothorax that points forward, about two thirds as long as seginent two of polyus.

The abromen is oval in shape, almost spherjcal; posterior margin bears four pair of short, stout, bristles subequal in length. There are a few short hairs around the sides of the abdomen.

The two hind pairs of legs are longest and of almost equal length; two front pairs are shorter and also of almost the same lengtin. The first jair of legs is a little longer than the palpus; the tarsus is the longest segment; femur almost as long; segment linree two trirds as long as four; both together as long as tarsus. There is aring ristle on the distal end of tibia of leg I, a similar but longer bristle on tibia of leg four and a bristle on the proximai end of tarsus of leg four as long as the segment iiself; a similar kut not so long a bristle on the tarsus of leg three.

The abiomen is a dark brown color, almost black; the rest of the hody is colured orange. The legs and palpi are lighter in color.

The texture of the iriegrerte is roderately smooth and rather tough. 

Distribution,--

Norwe, described by Sigi. Thor.

United States, collected by myself, Urbana, IIIinois.

Collectiuns were made from under boards and rubbish.

Bde11a tenuirostris Eoch .pl.6, figs.l,2.pligigs.l,2.

1834, C. I. Koch, Deutschl. Crust. Mirjap. Arach.,Hef.23, Taf.18.

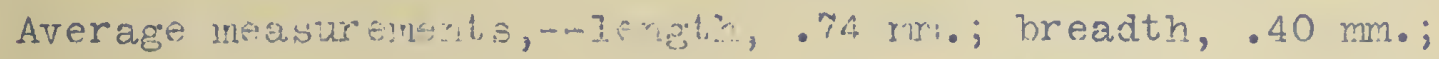

length of mandibles, .24 mm.; palpi, .40 mm.; fjrst pair of legs, $.62 \mathrm{~mm}$; second peir, $.50 \mathrm{~mm}$; thira pair, .74 m.; fourth pair, $.88 \mathrm{~mm}$.

The mandiblos are arout half as long as the body, not stout, but tapering; on each side of the mandibles are four small, slight ly curved bristies.

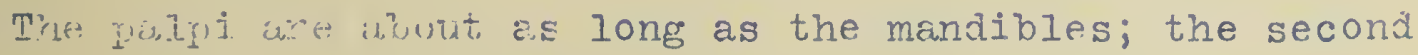
segment is almost threc times as long as the distal segment; segmentsfinree and four of equal lengtin; both together ahout three fourths the lergyth of the distal segment. Distal segment ends abruptIy, the distal end being broader than the proximal. At the

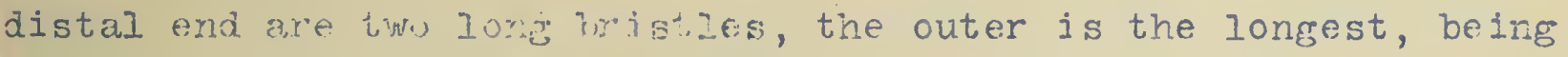

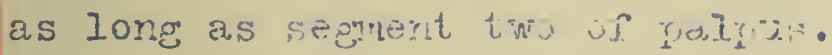

The Eeneral shape of the thorax is that of an isosceles trapezoid with the sides slightly concave, and the upper side about one linird the wicin of the base; on each side at the posterior margin are two eyes, in front of which on each sije there is a short brislit. A large pair of bristles are situated on the anterior is sil part of the cephalothorax. Between the pair of eyes are two somewhat small bristles. The abdomen is about two thirds as wide as long; on the dorsumare 

two rows of

rather large bristles also a row of similar bristles around the margin; on the posterior margin is situated two pairs of molerateIy large bristles of equal size and length.

The posterior pair of legs is the largest and longest. The first pair is about half as long again as the palpus; the tibia and tarsus, the longest segments are subequal; segments thre and four subequal, taken together they are as long as the tibia; femur three fourths as long as the tibla. The second pajr of legs are the smaIlest; the third pair are almost as long as the fourth pair. The proximal end of tarsus three and four each carries a long bristle. The tibia of four also has a long bristle, about one half the length of the bristle on the tarsus.

Most of the mandibles, the cephalothorax, the legs and antennae are a resiish pink. The tips of the legs, mandibles, and posterior part of the cephalothorax and anterior part of the abdomen are a very pale, greenish, yellow; the rest of the abaomen is green exceit a yart of the posterior end which is red.

The skin is rough and not as tough as usual.

Distribution, - -

Germany, described by C. L. Koch.

United States, collected by myself, Urbana, Illinois.

\section{Bdella n.sp. .}

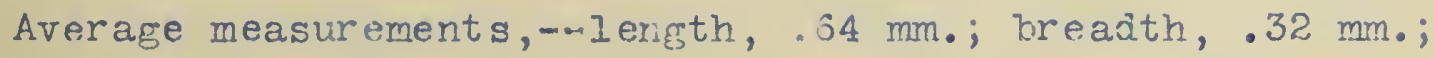
lengtin of manoibles, .16 mm.; palpi, .22 mm.; first pair of legs, . 36 mm.; second pair, $.34 \mathrm{~mm}$; third pair, .40 mm.; fourth pair, $.56 \mathrm{~mm}$.

The mandibles are short and stout, being a little over half 

as long as the cephalothorax. There is a bristle on each side of the mandibles close to the base, and one on each side about one third the disture from the tip.

The palpi are a little longer than the mandibles; segment two longest, almost as long as the mandibles. The distal segment is about haly as Jong and broader at the tip than the base. At the end there are two long bristles, the outer is the Ionger, being as long as the mandibles; two short bristles on the outside edge of the segment; segments three and four broader than Iong. The cephalothorar is much longer than broad, sides convex. The abdomen is Iong and oval. There are four short bristIes near the median line on the posterior margin of the abdomen.

The legs are subequal, the posterior pair is silghtly the longest. The second pair is shortest.

The tarsus of leg one is the longest segment; tibia two thirds as long as the tarsus; femur as long as the tibla; segments three and four subequal, taken together a little longer than the tibia. Tibia of leg one bears a long bristle near the distal end. The tarsus of leg three and four each bears a similar bristle.

The mite is almost a uniform light yellowish-lorown in color. The appendages are Ijghter than the body.

The surface of the integument is smooth. Skin not as tough as usual.

Distribution, -.-

United states, collected by myself, Urbana, IIIinois. 

Bde11a. 2.sp. ,pl.7, fig. 3.

Average measurements, -.length, $.60 \mathrm{~mm}$; breadth, $.26 \mathrm{~mm}$;

length of manibles, $.20 \mathrm{~mm}$; palpi, $.30 \mathrm{~mm}$; first pair of legs, $.44 \mathrm{~mm}$; seconi pair, $.38 \mathrm{~mm}$; thira pair, $.52 \mathrm{~mm}$; fourth pair, $.56 \mathrm{~mm}$.

The mandibles are short and broad at the base; at the middle on each jide is a large curved bristle and at the base on each sile is a similar bristle of about one half the length of the first named.

The palpi are longer than the mandibles; second segment much the lorgest being almost as long as the mandibles; fourth segment not quite as long as the third, both together as lons as the distal segment; distal segment broader at the tip than at the base and bearing two large bristles, the inner of which is spiral shaped, very characieristic of this species. Two small bristies are situated at the base of the larger ones.

The cephalothorax is longer than broad with a neck in front, sides convex. At about the midale on each side is situated a very long bristle, as long as the mandibles, behind which are the eyes, two on each side. Just behind the eyes and a little median to them are two bristles which point outwards and backwards. Lateral to these on ine margin is a pair of bristles equal in length to the former.

The abdomen is oval, tapering slightly towards the posterior end. It has a row of bristles on the dorsum on each side about four in number. There are several bristies on the posterfor margin of the abdomen. There are two larger than the rest, very close to the medien line.

The legs are of about the same length. The second pair is 

shortest. The tibia of leg one is ahout two thirds the length of the tarsus the longest segment; segments three and four are subcqual; together trey are as long as the tibia; the femur is large, almost as long as the tarsus. The tarsus of leg three bears at its proximal end a very long bristle, as long as the segment

itself. The tarsus of leg IV has a similar bristle, also one not quite so long is on the tibia.

The color of the body is yellow with a shade of green. The sides of the thorax, the palpi and the legs are rose red.

The integument is moderately rough and moderately tough. Distribution, --

United stides, collected by myself, Urbana, Illinois.

\section{Bde Ila n.sp. .}

Average measurements, - - length, $.90 \mathrm{~mm}$; breadth, .42 m.; length of mandibles, $.40 \mathrm{~mm} . ;$ palpi, .60 mm.; first pair of legs, $.66 \mathrm{~mm}$; secorda pair, $.60 \mathrm{~mm}$; third pair, $.66 \mathrm{~mm}$; fourth, $.80 \mathrm{~mm}$.

The mandivles are long an narrow, carrying two bristles on each side close to the center. The posterior bristle is longer than the anterior.

The palpi are a little longer than the mandibles; the second segrent is two thirds as long as the mandibles; distal segment half as long as segment two and carrying two bristles on the end; the outer bristle is as long as the segment itself; the inner hristle is about two thirds as long; on the side of the segment is a similar brist.e; segment four is two thirds as long as distal segment; segment three one half as long as four.

The cephalothorax is longer than broad, sides concave; on each sile is a long erect bristle one third as long as the man- 

dibles. There are three eyes on each side of the cephalothorax situated near the posterior nisgin of the same. The ocular regior of the cephalothorax is very convex.

The abiomen is globular, it has about eight short bristles on the posterior mar $\mathrm{g}^{\mathrm{i}} \mathrm{n}$.

The rirst bio pairs of legs are subequal and are shorter than the two posterior pairs, which are subequal. The tarsus and fernur of leg I are guenuri tine tibia is about two thirds as long as the tarsus; segments three and four are subequal, together they are about as long as the tibia. There are no long bristies on the legs.

The legs, lralri, mandibles and the anterior part of the cephalothorax are yellow, the rest of the body is yellow spotted with purple.

The surface of the integument is almost smooth; integument tough.

\section{BdeIIa n.sp. pl.8, figs.2,3,4.pl.q. fig.l.}

Average measurements, - IEligth, $1.20 \mathrm{~mm}$; breadth, $2 \mathrm{~mm}$; length of manililes, $.38 \mathrm{~mm}$; palpi, $.36 \mathrm{~mm}$. F first pair of legs, $.80 \mathrm{~mm}$. ; second pair, .74 mm.; third pair, $.96 \mathrm{~mm}$; fourth pair, $1.10 \mathrm{~mm}$.

The mandibles are thick, about as long as cephalothorax, broad at the buse; two large bristles on each side near the end, and a small bristle on each side at the base.

The second segment of the palpus is as long as the mandibles, tinird and fourth segments of equal length, both taken together are half as long as the distal segment, distal segment has two large bribties at the end, the outer about as long as segment 

two, the inner almost as long as the outer.

The cephalothorax is broader than Iong, sides convex; two long bristles in front at the sides, pointing forwards and about as long as the fermur of leg I, two much smaller bristles on each side, posterior to the larger ones, the hind pair is the longer, three eyes on each side at the posterior, dorsal margin.

The abdomen is large and broad, almost as broad at the posterior end as at the anterior end. The progaster has two bristles on each side, the thterior twice as large as the posterior. The posterior margin of the notogaster has two pairs of large bristles near the median line and two smaller pairs about two thirds as long, farther away from the median line.

The third and fourth pairs of legs are subequal. The fourth pair is mach thicke: than the third. The first pair of legs are longer than the second pair; the tarsus is the longest segment, with the tibia and femur almost as Iong; segment three and four equal, both together almost as long as the tibia. No long bristles on the legs.

The mite is a vermilfion red in color. The legs are not so dark.

The 1 integument and

Distribution, - -

United States, collected by myself, Urbana, Illinois.

Subfamily Eupodirne.

Linopodes antennaepes Banks.

1894, N. Banks, New American Acarina, Trans. Amer. Entom. Soc. 1905, N. Banks, The Acarina or Mites, Proc. U.S. Nat. Mus., vol. 28, p. 13 . 

Average measurements, ..length, $.56 \mathrm{~mm}$; breadth, $.36 \mathrm{~mm}$; length of maniibles, .II mm.; palpi, .22 mm.; first pair of legs, $1.90 \mathrm{~mm}$; second peir, $.70 \mathrm{~mm}$; thira pair, $.50 \mathrm{~mm}$; fourth pair, $.60 \mathrm{~mm}$.

The mandibles are three fourths as long as the palpi and very stout.

The distal segment of the palpi is one half as long as the penultimate; penultimate has a straight bristle on the dorsal surface in front; antipenultimate has a similar but longer and curved bristle on tis iorsal surface, antipenultimate is about twice as thick as penultimate and is a little longer; base of palpus is very narrow.

The cephalothorax is joined to the abdomen so that no division can be noticed.

The abomen is about as broad as thick, there are about six curved bristies or. line posterior margin of the abdomen.

The anterior pair of legs are about three and one half times as long as the body; basal segment two thirds as broad as thick; segment two, short, tringular; segment three of leg I a little longer than body; gegment four three fifths as long as three; four and rive subequal; five has a short, straight bristle on the end away from the median side; it also has several other very short bristles. Legs two, three and four, subequal and possess several rather slevier bristles.

The body ig pale greenish-yellow; appendages yellowish-brown. The skin is soft and delicate, the surface rough. Distribution,--

United States, reported by N. Banks, Sea Cliff, N. Y. United States, reported by N. Banks, Ft.Lee, N. T. 

United states, reported by $N$. Banks, Chicago, IIIinois. United States, reported by Mrs. A. T. Slosson, Franconia, N.H. United states, collected by myself, Arcola, Illinois. United States, collected by myself, Urbana, Illinois.

\section{FAMIIY TROMBIDIDAE.}

Subfamily Erythraenae.

Actineda agllis. pliro, figel.

1894, N. Banks, New American Acarina. Trans. Amer. Entom. Soc., vol. $21, \mathrm{p} .21 \mathrm{l}$.

Average measurements, - length, $1.08 \mathrm{~mm}$; breadth, $.94 \mathrm{~mm}$.; lenfth of palpi, .48 mm.; length of first pair of legs, $1.40 \mathrm{~mm}$. ; second pair, $1.40 \mathrm{~mm}$; thirà pair, $1.34 \mathrm{~mm}$; fourth pair, $1.44 \mathrm{~mm}$.

The manihles are about three fifths as long as the palpi and broad at the base; fingers smal], about one eighth as long as the rest of the mandilles; each mandible has a long bristle on the upper side about the midale and another similar bristle about one third the distance from this bristle to the end of the mandiole.

The palpi are about one third as long as the first pair of legs; basal segment is as broad as long; distal segment about the same lengti as segrayt two; segment two has about half a dozen long bristles; the distal segment has many somewhat smaller bristies.

The body is about as broad as long. It has a fert long bristles. The body is broadest at the posterior end.

The legs are all about the same length; leg $I$ is a third thicker trian leg IV. The anterior pair of legs is half as long again as the body. The legs are clothed with hairs and also possess several long bristles which are about three times as long as 

the hairs: The tarsus of leg I is two thirds as long as the tibia. The mite is a light brown color. The skin is rather thin; the surface is slightly rough. Distribution, --

Now York, reported by $N$. Banks, Sea Cliff, I. I. New Jersey, reported by N. Banks, Ft. Lee. Illinois, collected by myself, Urbana, Illinois.

Found running over shrubs and other plants. Collected in winter from under boards.

\section{Subfamily Tetranycinae.}

Bryobia praetiosa, pl.11, fig.l.

1842, C. I. Koch, Myr. Crust. Arach. Deutsche.,fasc. 1, fig.8. 1842, C.I. Koch, (B.gloriosa) Crust. Arach.Deutsche.,fasc.l,fig.9. 1877, Canestrini and Fanzago. Acar. It., p. 91. 1886, A. Berlese, A. M. Sc. It., fasc. 33, n. I. 1891, R. Canestrini, Acarofanna It., p. 441. 1905, N. Banks (B. preatensis), Acarina or Mites. Proc. U.S. Nat. Mus., vol. 28, p. 26. Average measurements,--length, $.84 \mathrm{~mm}$; breadth, $.40 \mathrm{~mm}$; length of palpi, $.08 \mathrm{~mm}$; first pair of legs, .90 mm.; second pair, $.44 \mathrm{~mm}$; third pair, .44 mm。; fourth pair, $.46 \mathrm{~mm}$.

The mandibles are small; do not extend to end of palpus. The palpi are about twice as long as the second segment of leg I; palpi end in a very short, curved claw and a stubby thumb of about tine same length as the claw. The thumb has about four long bristies wich are about as long as the thumb itself.

The four scale-like projections of the front margin of the cephalotiorax extend forwards as far as the end of the palpi; the 

free scales of the two outside projections are almost twice as long as tine scales of the inside projections; the free scale of the outside projection is about one half as long as the projection itse Ir; thase of the inside projections are about one fourti as long as the projection itself; body has several scale-like bristles; body is chout, as thick as broad and about two thirds as broad as long.

The first pair of legs is longer than the body. The hind pair of legs is about two thirds as long as the body; the second and third pair of legs are subequal. The third segment of leg I is the longest segment; segment four is about two fifths as long as segment thret; segment ive is twice as long as four. The tarsus is about three fifths as long as segment five. The tarsus has about, a lozen bristles, three at the tip being longer than the rest. The tarsus and tibia of the other legs are of almost the same length.

The color is a reddish brown. The body is almost black. The skin is of moderate thickness, surface of skin is rough, boty has small parallel furrows on the dorsum.

Distribution,--

Germany, described by C. I. Koch.

Italy, described by $A$. Berlese and R. Canestrini.

United States, described by N. Banks.

United States, collected by muself, Urbana, Illinois.

This mite lives upon plants. It is collected from plants and fron the bark of trees and under boards. Mr. Hart finds many of them on goose berry leaves. 



\section{Subfamily Trombidin e. \\ Ottonia locustarium. Riley}

1877, C. V. Riley, (Trombidium 1.). The locust mite. First Rep. U.S. Fntom. Com., p. 307.

1894, N. Banks, New American Acarina. Trans. Amer. Fntom. Soc., VoI. 2I, ?. 213

Average measurements,--length, $2.6 \mathrm{~mm}$; breadth $1.8 \mathrm{~mm}$; length of palpi, .80 mm.; first pair of legs, $2.20 \mathrm{~mm}$; second pair, 1.30 mm.; third pair, $1.80 \mathrm{~mm}$; fourth pair, $2 . \mathrm{mm}$. The palpi are about one third as long as the first pair of legs. The palpus possenses at the distal end two large hooks or claws, the outer of which is much the stouter and not so sharp as the inner; in adition there are three minor straight claws on the outer ventral margin of the distal segment. The thumb of the palpus is almost as Iong as the segment to which it is attached. It is aInost cylinir ical though slightIy clavate and is thickly covered witin ratiner short hairs.

The mandibles are two fifths as long as the palpi and possess a piercing organ on the inner side at the end; the piercing organ is about as Iong as the thumb.

The two eyes are situated on a pedicel at the sides of the cephalothor ax.

The abiomen is pyriform in both sexes; the abdomen of the male is very broad in front and narrow behind, being almost as broad as Iong; in the fernale the abdomen is not so broad in front as in the male, but is broader benind. The anus is situated on the dorsal side; it is very large and is approximate to the postorior margin of the abdomen. The abdomen is thickly covered 

with fine feathery hairs. There is in the male a deep transverse groove on the durseil surface of tine anterior part of the abdomen; the groove extends over one half the way across the abdomen.

The first pair of legs is about as long as the body; the hind pair is of about the same length, while two and three are shorter; segments four and five of leg I join each other at an angle or about $120^{\circ}$; the tibia of leg I is a little longer than the tarsus; the tarsus is broader at the tip than at the base and is thiciy clothed with fine, short, plumose hairs. The claws of leg I are verv snall in comparison with the claws of the other legs. They are about two fifths as long as the other claws. The color of the mite is a uniform bright, showy red or scarlet.

\section{Distribution,--}

United States.--It has a general distribution over the midale west and southern part of the country. I have collected specimens in both Mississippi and IIlinois.

\section{Ottonja n.sp.}

Average measurements, --1ength, $4.50 \mathrm{~mm}$; breadth, $3.10 \mathrm{~mm}$; length of palpi $1 \mathrm{~mm}$; first pair of legs, $2.80 \mathrm{~mm}$; second pair, $1.90 \mathrm{~mm}$; third pair, $1.90 \mathrm{~mm}$; fourth pair, $2.40 \mathrm{~mm}$.

The paIpi are thick ani stout, as long as the first three segments of $\operatorname{leg} I$; segment two broadest, being three fifths as broaxi as Iong; segment three broader than long; segment four ending in two glout, curved claws, the outer is the largest and strongest. The thumb is about as long as segment four, and one third as broad is 10rg. It is E.Imost cylinoirical in shape and is covered with many feathered hairs. 

The cephalothorax is almost completely hidden from above by the projection of hine ikciomen. The mandibles are two thirds as long as segrent tivo of the palpi and ends in a straight piercing claw, one half as long as the body of the mandibles.

The abdomen is oblong in shape, two thirds as broad as Iong, slightIy hroader in front, and ending behird in a blunt oval apex. Jegs three and four have their origin together on either side of the abdonen velow and about one half the distance from the anterior to the posterior end. The genital opening is about.two thirds as broak as long misis situated slightly posterior to the hind pair of legs.

The iecs are short. The anterior pair is not quite as long as the body, the second and third pairs are much shorter. The posteriur peir of legs extends scarcely beyond the margin of the abdornen.

The coxa of leg one is the broadest segment; it is two thirds as broad a Iorg; segment two is about one half as Iong as the cuxa; three is ahout three times as long as two; four is two thirds as long as three, five is a little longer than four; six is hale agin dis lone as five and the distal segment is about the same length as six and broader at the tip than at the base. Hairs form a whor 1 at the djstal ends of all the segments. The color of the mite is a uniform red, rather bright. Distributior,,$-\infty$

United States, collected by myself, Urbana, Illinois. Found on plants and running around on the ground. 



\section{Trombidilim n.sp. .}

Average measurements, - - length, $2 \mathrm{~mm}$; breadth, $1.80 \mathrm{~mm}$; length of palpi, $.80 \mathrm{~mm} . ;$ first pair of legs, $2 \mathrm{~mm}$; second pair, $1.50 \mathrm{~mm}$. ; third pair, $1.20 \mathrm{~mm}$; fourth pair, $1.60 \mathrm{~mm}$.

The palpi are a little longer than the first three segments of leg I. The second and third segments are as broad as long. The fourlin gegment is rather short and tapers rapidly to form a stout curvea claw which is about as long as segment three. The thumb is as long as segrent four and is inserted near the base of the segment four on the ventral side; it is clavate, almost in the shape of an Indian club, though rounded at the end, rather thickly clothed with short feather hairs.

The cephalothorax is almost rectangular in shape. Ocular segnent is ihout as long as segment two of leg I, and clavate; mandibles tricki us lorg as segment two of leg I. Each mandible ends in a piercing organ, winch is curved towards the dorsal plane and is slerier and tapering.

The abdomen is as broad as long, almost square but broader in front than behind. Hairs of the ahdomen thick; clavate in shape rith swelling at the end, also denticulate. Genital aperture is twice as Iong as broad, situated just behind the hind pair of legs. A long transverse groove is situated on the ventraI side or the didomen closto the posterior margin.

The anterior pair of legs is a third longer than the body; the posterior pair extends two thirds its length beyond the margin of the abdomen. The coxa of leg I is twice as long as broad; segment two the shortest, is one thira as long as the coxa. The tibja and tarsis are subequal; tarsus broadest at the distal end; 

the aistial enci is turned in to form a sort of a groove, from which the claws extend. The tarsus is thickly covered with very short feather hairs.

The rite is didrk red in c:olor.

Distrifoution, --

united states, collected by myself, urbana, Illinois.

Found on plants and running on the ground.

\section{Subfanily Rhyncholophirae. \\ Rhyncopholus Piludicola Koch.}

1834, C. I. Koch, Deutsche. Crust. Myr. Arach. Heft.16. Taf. 14. Average measurements, -..length, .90 mm.; breadth, $.50 \mathrm{~mm}$.; length of palri, .28 m.; first pair of legs, $1 \mathrm{~mm}$; second pair, $.66 \mathrm{~mm}$. ; third pair, $.80 \mathrm{~mm}$; fourth pair, $.90 \mathrm{~mm}$.

The palni are about as long as segments two and three of leg I; segment four very short, hardly half as Iong as three and ending in a small, short, curved claw; about one fourth as long as the rest of the surner. Trumb situated close to the end of segment four, twice as long as broad and clothed with a few, stout hairs.

The cephalothorax is of medium size. The mandibles are large, two thirds as long as the palpi; piercing organs one half as long as the rest of the manilbles and tips curred slightly towards the medicin plarne.

The abivin is three fourths as broad as long, moderately well clothed with stout short hairs; hairs more numerous around the posterior rargin of abdomen.

The anterior pair of legs is half as long again as the body, the rest are subequal. The coxa of leg I is broad and thick, seg- 

ment two is gomprat protder than usual; three is half again as long as two ank much narrower at its proximal end; four is twice as long as two; five is somewhat shorter than four; tibia is about the same length as four; tarsus is tvo thirds as long as the tibia; it is broader and oval at its tip, rather thickly clothed with hairs. The tarsi of the other legs are shorter and thicker and have on tineir anterior margin a row of hairs.

The color of the body is black; legs, palpi and mandibles are reà.

Distribution, - -

Gormany, described by C. I. Koch.

Unites States, collected by myself, Urbana, Illinois.

\section{Rhyncopholus n.sp.}

Average measurements, ..-length, $.88 \mathrm{~mm}$; breadth, $.50 \mathrm{~mm}$; length of palpi, .2. $\mathrm{mm}$; first pair of legs, $1.40 \mathrm{~mm}$.; second pair, $.96 \mathrm{~mm}$; third pair, $1 \mathrm{~mm}$; fourth pair, I mm.

The palpi are almost as. Iong as the first three segments of leg I; segment tvo three times as long as broad; segment four short and ending in a stout, curved, sharply pointed claw, which is almost as long ass the thurih and has a tooth on its concave surface. Thumb clavate, short, with several bristles, with one bristle longer than the rest close to the base.

The cephalothorax is about as long as broad; mandibles two thirds as long as the palpi, and possessing at their end a long, straight piercing organ as long as the body of the mandibles themselves. The manaihles have several rather short curved bristles near the end, one bristle being much longer than the rest and curred towarda the noàian plane. 

The abdomen is two thirds as broad as long and has a few short, stiff bristles.

The legs are very long; the anterior pair are almost twice as long as the bojy; the coxa of leg I is much the thickest segment; segnent two bout as long as coxa and sub-globular; segment three is twice as long as two; four and five are subequal; tibia somewhat shorter than sement five; tarsus about two thirds as long as tibia, being the thickest segment excepting the coxa; tarsus covered ifin hajrs. The tarsi of the other legs are, thicker and shorter and have a row of subequal bristles on the anterior margin.

The color of the mite is a dark red; legs paler than the body.

\section{Distributior,,-}

United Siafis, collected by myself, Urbana, Illinois. 

GIOSSARY .

\section{Abdomen.}

The posterior of the two large divisions of the body. It possesses few il min oxginis.

Anal nlate.

A large chitinous plate forming a part of the exogkeleton and bearing the anal aperture.

Anal plates.

Two chitinous "folding-aoors," closing the anus from the exterior. They form a part of the ventral exoskeleton. Bristles.

Stout hairs.

camerostome.

The opening, in the anterior part of the body into which the mouth parts are inserted.

Cephalothorax.

The anterior of the two large divisions of the body. It is usualiy pyranidal in shripe and ruch smaller than the abiomen.

chelate.

Pincer-iike, having parts opposed to each other. The manaibles of many genera are chelate, as well as those of all the familiss, Orinatikine, Gerksiae and Tyroglyphidae. clavate.

Having the form of a club, 1.e., growing gradually thicker toward the end. 

coxa.

The free segment of the leg, by means of which the leg is attached to the hody. The coxa is often small and rather obscure.

=Trochanter. (Pagenstecher Dugès)

= Hanche (Robin, Fumose, Dujardin, Mégtin)

= Exinguinal (Nicoiet)

=Racine du membre. (Donnadien)

cusps of the lamellae.

The portions of the lamellae that project in front of its articulation witic line ceprejothorax.

cuticula.

The external covering of the mite, synonymous with skin or dermis.

Denticulate.

Having branches resembling teeth. A much more general term than serrate or pectinate.

Dermis.

The external covering of the mite, gynonymous with skin and cuticle. The dermis is frequently heavily chitinized.

Dorso-vertex.

The dorsal surfoce of the cephalothorax behind the rostrum. Epimera.

Chitinous rod-like projections in the sternal cuticle, which form a rigid skeietor for the support of the legs.

Epistoma.
A thin corneous plate above the mandibles, notably present in Garnasidae. 

Femur.

The second segment of the leg counting from the body. It is frequent Iy the largest segment, though not the longest. =Femoral (Pazenstecker, Dugès, Nicolet)

= Trochanter (Robin, Fumose, Mégnin and Michael in earlier papers, Banks)

=Condyle (Donnaileu)

Flagellum.

A chitinous appendage having its origin near the base of the fingers of the mandibles in the gamas ic ae, and sometimes spoken of as a "spur."

Genae.

The sides of the rostrum. Each gena in some species ends anterioriy in a snali trees point.

Genital plate.

A chitinous plate forming a part of the exoskeleton and usually bearing the genital aperture.

Genital plates.

Two chitinous "foldingmäors," which when shut close the genital opening through which the exterjor genital organs are thrust. They form a part of the ventral exoskeleton.

Genual.

A term laged onli witi reference to mites having five segmants to the leg. In these it is the third segment, counting from the bokiy, i.e., mialle segment of the leg.

= Ia jambe (Duges)

= Femur (Robin, Fumose, Mégnin, Michael in earlier papers, Banks) 

= First article (Donnadieu)

Hairs.

The term hairs is used to denote such filaments of the cuticula as are relatively suli or confined to the body.

Hypostorne.

An articulated maxillary lip which partly closes the hood of the Rostrum below.

Inter lamellar hairs.

Two large bristles arising from the dorsal surface of the cephalothorax, in front of the pseudo-stigmata.

= Interstigmatic hairs (Nicolet)

Joint.

The articulation between two segments- not the segment itself.

LameIlae.

The lateral outpocketing of t.re cuticle of the cephalothorax. Usually blade-1ike in shape. Found in the Oribatidae. Lamellar hairs.

Two hairs or bristles usually found on the lamellae near their antertor enis. Mey are alvays directed forward. Mandibles.

The parts of the mouth used for graspirg food or prey. Very large and snout-Iike in Bdellidae; very small in Oribatidiat.

Notogodatir.

Tre (in)sil surface of the abdomen.

Palpi.

Conspicuous, long, antenniform organs arising from the front 

of the cephalothorax. They may have from three to five segments. The distal segment ends usually in one or more prominent fristles. The palpi are organs of touch and perhaps have other important functions.

Pectinate.

Resemiling the teeth of a comb. Used in the description of certain branched hairs and also of pseudostigmatic organs

Pedicel.

An appendage or segment supporting the eye, usually. cylindrical, but often clavate in shape.

Penultimate.

Next to the last segment of the palpus, counting from the body.

Progaster.

The anterior part of the notogaster.

Pseudomtigmata.

Two paired, chitinous, tubular organs situated on the dorsal surface of the cephalothorax close to its base and near the lateral margin. They were once thought to be true stigmata. Found in Orivatidae.

Pseudo-stigmatic organs.

Two paired organs, sometimes setiform, sometimes bulky and of various forms. They always proceed from the anterior part of the psevio-stigmata and usually are directed at about right angles to the surface of the body. pteromorphae.

Wing-like expansions of the cuticule on the sides of the abdomen. They sometimes project beyond the margin of the 

cephalothorax and abdomen. Found in the oribata and in Pelops.

Pyriform.

Pear-shapea. A term much used in descriptions of the body or abjomen.

Rostral hairs.

Usually two, sometimes four, paired hairs, on the rostrum near the anterior end.

Rostrum.

Usually a kind of a hood covering the trophi. It is that part of the cephalothorax in front of the dorso-vertex.

segment.

One of the pieces into which the legs, palpi etc. are divided. That portiun between two joints or articulations or beyond a aistal articulation.

= Joint (Michael)

serrate.

Notched along the edge to form teeth like those of a saw.

Used in descriptions of hairs and pseudo-stigmatic organ. Sessile.

Sitting directly on the body without any support. setae.

Small bristles, especially when they have unusual forms. setiform.

Having the form of a bristle. Long and tapering. spatulate.

Shaped Iike a spatula or resembling a spatula, i.e., flat, with oval margin, broader at the distal end and with a 

narrow base.

spiracle.

A breathing pore usually situated near the mouth or on the sides of the body not far froin the postor tor cokt, as in the Gamas idae. Not all mites have these spiracles.

spur.

A projection or appendage which arises near the base of the fingers of the mandibles in the Gamas id af though the is term^sometimes used in a general way.

sternal plate.

A thick chitinous plate situated on the sternum. It forms a part of the exoskezeton.

Tactile hair.

A long bristle on the anterior surface of the distal end of the tibia. More often present on the tibia of leg I.

Tarsus.

The distal segment of a leg.

= Metatarsus (Nicolet)

$=3 r d$. article (Donnadieu)

Tibia.

The second segment of the leg, counting from the distal end of the leg.

= Jarnbe (Robin, Fumose, Méénin)

=4th joint (Michael, in earlier papers.)

$=2$ nd article (Donnadieu)

=Penultinate (Banks)

Translamella.

A chitinous ridge or it may be only a line, joining the 

lamellae at the base of the cusps and bordering the dorsovertex anterioriy. Founi in some of the oribatidae. Ventral plate.

A chitinous shield covering the veritral surface of the abdonen. It is pierced anteriorly by the genital aperture and in the posterior region by the anus. 



\section{BIBLIOGRAPHY.}

Auriviliius, W. S.

1887 - Beobachtungen über Acariảen Auf den Blättern Verschiederer Bame. I6 fp., 1 pI.

Banks, N.

1894 - Some New Amerjcan Acarina. Trans. Amer. Entom. Soc., vol. 21, pp. 209-222. (Contains descriptions of twenty three new species. Trets of forms relonging to the super families Trombisuided and Eupodoidea; most of the specimens being collected from Long Island, N.Y.).

1895 - Some Acarians from a Sphagnum Swamp. Jour. N.Y. Entom. Soc., vol. 3, pp. 128-130. (Contains descriptions of five new species of mites. The collection was made from a swamp near RosIyn, I..J., N.Y., which was coverea with a few inches in water and contained an abundant growth of sphagnum.

1895 - The Arachnida of Colorado. Ann. N.Y. Acad. Sci., vol. 8, $\mathrm{pp} .416-434$. (A Iist of eighteen species found in Colorado. One nern sevies described).

1895 - New American Acarina. Trans. Amer. Entom. Soc., vol. 22, pp. 1-16. (Treats of the Oribatidae of the United States. There are thirty-two new species described under the rame of a super family oribatoidea. Three species, (two being new) are described under the family Hoplophoridae). 

1896 - American Aptera. Trans. Amer. Antom. Soc., vol. 23, pp. 57-77. (Tourteen new species described: one Trombidiun, two Ottonia, one Rhyncolophus, one Smaris, one Bdella, one Eupodes, two Oribatella, one Belba, one Eremaeus, two Caratodes, and one Nothrus (?)).

1904 - Some Arachnida from California. Proc. CaI. Acad. Sci.spr.3, vol. 3, No. 13, pp. 332-376 figs., (Contains many descriptions of gecies).

1905 - Descrifing of Some New Mites. Proc. Entom. Soc. Wash., vol. 7, Nos. 2-3, pp. 133-142, 4 figs. (Twenty new species described).

1905 - The Acarina or Mites. Proc. U.S. Nat. Mus., vol. 28, pp. 1-109, 201 figs. ('his is the only American work that deals with the classification of mites in general. It contains no description of species, but has an excellent key for the despritinetion of the known American genera. In this artirle Barks divides the order Acarina into eight superfamilies and these again into twenty six families, no sianfarmijes reing used. Most of the European authorilies orit, the division into superfamilies but many use sub-families. The life histories of the different fanilits are sumarized, as well as the distinguishing characteristics of the different genera. Berlese, A.

1883 - Escursione in Sicilia, Acarofauna Sicula. $1^{a}$ Serie. vol. 15, $\mathrm{pp}$. 212-220. (Has classification into families and species. Fifty-zive species found in sicily). 

1885 - Acarorum Systematis. Buld. Soc. Fintom. Ital., vol. 17, $\mathrm{pp}$. 121-135. A systematic classification of genera only. (He divides the acarina into seven families including twenty-four sub-families and 103 genera).

1886 - Acari Austro-Americani. Bull. Soc. Entom. Ital., vol. 20, $\mathrm{pl}$. 171-258, 9 pls. (Contains descriptions of 75 species including many new ones. Figures are given in the back of volume. Descriptions and figures from mites of the funities Tromididue, Gamasidae and Oribatidae).

1397 - GIi Aceuri Agrarii. (Estratto dalla Rivista di Patologia Vegetale, de.I' anno VI-1897, aII’ anno VIJI-1899) 112 figs. (Is good for systematic work and gives thoroigh descriptions of species. Has an introduction upon the anatomy of mites).

1902 - Acari sud Americani Zool. Anz., vol. 25, pp. 12. (Descriptions of twertis - two new species, three new genera. Most of specirners vere collected from Chile). 1903 - Acari Nuovi. RediaI, 1903, 1: pp. 235-252, and pp. 258-280, $20 \mathrm{pls}$. (Contains many descriptions. The work is entirely upon Gamasidae or Mesostigmata). 1903 - Illustrazione iconografica degli Acari mirmecofili. Redia, $\rho$ 299-474. Also rev. 84I- N.S. I-43.

1904 - Acari Nuovi. Redia, 2; pp. 10-32, 2 pls. (Descriptions of forty-three new species and seven new genera). Butler, T.

1904 - The Cattle Tick and its Relation to the Cattle Industry of Nortin Carozina. N.C. Department of Agriculture. 

Canestrini, G. e Fankago, F.

$1.87 \%$ - Intorno Agli Acari Italiani. Atti Reale Instituto Veneto Sci. Let. Arti, ser. 5, vol. 4.

Canestrini, G. and Kramer, P.

1899 - Acarina: Demodicizae und Sarcoptidae. Das Tier., Lief. 7, Berlin. 193 pages. (A complete review of these two families including the reduction of synonomous species. Givrs koy to cinstijication).

Carpenter, G. H.

1905 - A New Oribatid Mite. Proceedings of the Royal Douklin Society., vol. 1, part 6, p. 294, pl. 25. carpenter, W. B.

1891 - Mites, in his work. The Microscope and its Revelations. pn. 932-933, 3 pls.

Claparèce, $\mathrm{E}$.

1868 - Studien An Acariden. Zeits. Wissen. Zool. Leipzig, pp. 445-540, Taf. 30-40. (Figures are given showing the develoment in ine emmological stage).

Dugès, A.

1834 - Sur Ins Acariens. Ann. Sci. Natur. Zool., ser. II, T. 2, 1834, pp. 18-63, pls. 7 and 8. (Good descriptions of genera, Drawings mostly of parts only one fig. of specinen.

18.34 - Recherches sur I' ordre des Acariens en général et la famille des Trombiaies en particulier. Ann. Sci. Natur. Zool., pp. 5-46, I pl. (Good descriptions of genera). 

Frageatt, W. W.

1901 - The Fow Tick. Agricultural Gazette, N. S. Wales. Nov .

Für stenberg, M. H. F.

1861 - Die Krätzmilben der Menschen und Thiere. Leipzig. 240 pages, 15 gla. (Has a bibliography of two-hundred and ninety-seven references).

Garman, H.

1894 - A Plum Twig Gall Produced by a Mite. From 7th Anrual Report or Ky. Agricultural Experiment Station. (One rigure).

Haller, J.

I8so - Zur Kenntnis der Tyroglyphen und Verwandten. Zeit. Wissen. Zool., vol. 34, pp. 255-295, Taf.9-2I. (An excellent work on hi'stology and internal anatomy).

Henking, $\mathrm{H}$.

I882 - Biologis von Trombidum fuliginosum Herm. Zeits. Wissen. Zool., p. 597.

Herrick, G. W.

1902 - The Chicken Mite. Miss. Agr. Exp. Sta. BuIl., No. 78,1 fig.

Karpelies, I.

189] - Bausteine Zu ejner Acarofauna Ungarus. 54 pages.

1894 - Anatory of Bielia Arenaria. Abstr. in Jour. Roy. Micro. Soc., London, p. I, p. 448.

Koch, L.

1879 - Arachniden aus Sibirien und Novaja Semlja. Stockholm. 136 pages, 7 pis. (Descriptions of thirty new 

Koenike, F.

1898 - Hydrachriden Finra von Madagaskar und Nossi Bé. Frankfurt. 138 pages, 10 pls. (Mostly new species descrined).

Kramer, P.

1876 - Die Familie der Bdelliden. Arch. Natur., vol. 42, pp. 183-136, I plate, 3 figs.

KuIczyńszi, V.

1902 - ZoOIogjische Fre nach Spitzberyen. Araneae et Oribatiae. I plate, 25 figs. (Descriptions of ten species, one being new).

Leonarii, G.

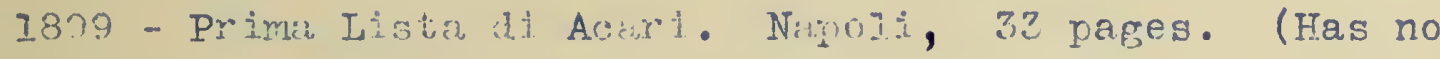

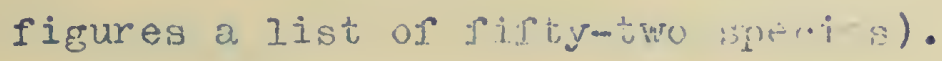

Mrégnim, M. P.

I87n - Momegrapte le Ferilile des Gamasids. Jour. Anat. e Phy., vol. 12, pp. 288-336, pl. 7 and 8. (Much of the article is given to the anatomy in general including internal anatorn and the pune i ms or the various organs. Has a gool key for tif classifjcation of

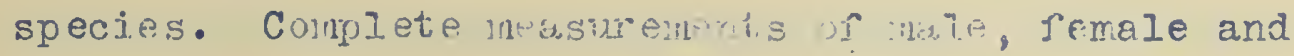
nympin given).

Michael, A. D.

1383 - British Oribatidae. Ray Society, vol. 1, 333 pages, 29 plates. (The drawings are excellent, including some colored rigures. The descrithing of the English species are the most cundete of try of thit Erelish investigators. Mr. Michep ma ke ha Mrvires from live 

specimens and in nearly every case worked out the life history of the different species. This was done by

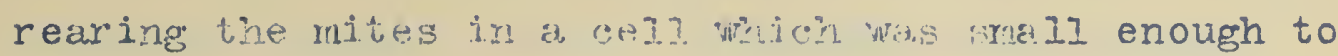
be placed on the stage of the injeroscure).

1887 - British Oribatidae. Ray Society, vol. 2. (This volume is a continuation of the work given in volume $I$. In this work Michel curndetes the list of British species or oribatidae. In the heck part of the volume he treats of trie internal andion of the igrming, and

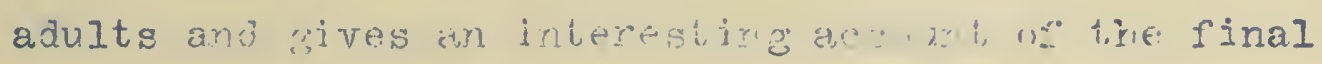
change from nympit to irrag. A Ilst or rorejgn species found in England, and a bibliography of nine pages is giverl in line back of the work).

1894 - Notes on the Uropodinae. Jour. Roy. Micro. Soc., rol. 8, np. 289-319, 2 plates, 15 rigs. (The internal anatomy of Uropodinae is described, figures being used in the descriptions. Three new species are described and many old ones ilent ipiei).

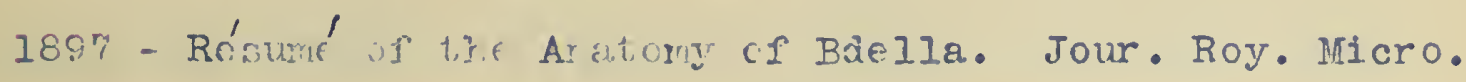
Soc., p. 2, pp. 3.03-1.06. (In thjo arkiness the author

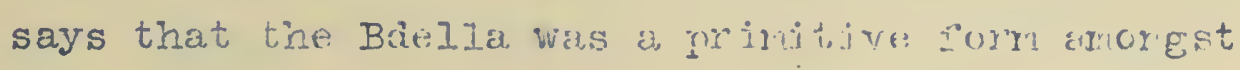
Ac:eri Enci one of the nearest to other Ercurs such as insects from a phylogenetic point of view).

1898 - Oribatidae. Das Tier., Lief. 3, 93 pages. (Excellent treatise for the therbiriction and ciessitica-

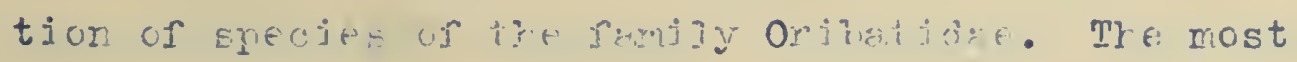
complete revifur of the fanily at wrespet. Inciudes several figur $\Leftrightarrow$ as well as a cey por identification of 

species).

Monì, R.

$$
\begin{aligned}
& 1.905 \text { - Goners "Srecie Nuorl ll Idracniae. Estratto da1 } \\
& \text { "Renaiconti" del R. Ist Lomb. disc. e Iett, Ser. } 2 \text {, } \\
& \text { VoI. } 38 .
\end{aligned}
$$

Müller, $0 . F$.

1881 - Hyarachnae. Lipsiae, 78 pages, 11 pls.

Murray, A.

1376 - Fconomic Entomology, Aptera. South Kensington Museum Science Handbook, Jondon. 433 pages and many figs (For many vears thjs was the only work open to English Zoologists. Descriptons are Inconpietir in the clas-

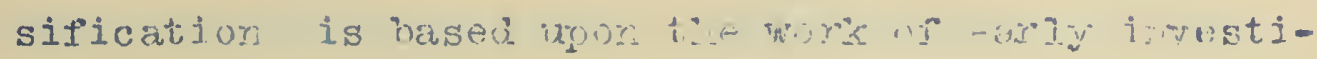
Eשt(irs).

Na.iepe, A.

I695 - Erimgridere. Das Tirr. Lief. 4. Berlin, 74 pages.

(A good key for identification. Characteristics of the family explained in detail at the beginning).

Neuman, C. T.

$$
\begin{aligned}
& 1880 \text { - Sveriges Hydrachyiler. } 12.3 \text { pages, } 14 \text { pls. (Many } \\
& \text { new species iesoribei). }
\end{aligned}
$$

Nicoiet, M. H.

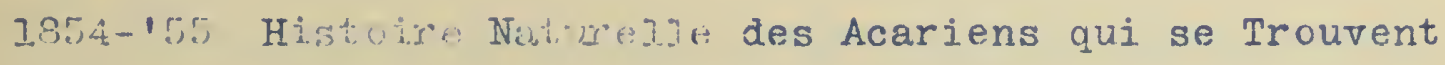
aux Environs de Paris, 100 pages, 9 pls. (Excellent drawings. Colored plates on internal anatomy).

Osborn, H. arid Undermoor, M.

1886 - Projininary Ljst of the Species of Acarina of North America. Can. Fntom., vol. 18, nr. 4-12. ! A Ist of 

97 specips givan).

Ou ingars, A. C.

1901 - Notes on Acari. Tijdschrift der Neder landsche Dierkundige Vereeniging. 2nd ser. Ieiden, Nov., pp. 50-87, pl. 1-3. (Descriptions of eleven new species, and one ner erenis).

Packara, A. S.

1873 - Tho Arth Fetirg Mite. Third Annual Report on the Injurious and Beneficial Insects of Massachusetts. pp. 20-27. (Has figure, doubtful specjes).

Perrier, E.

1893 - Acarina. Traite de Zoologie. Pt. 1, p p. 1115-1121.

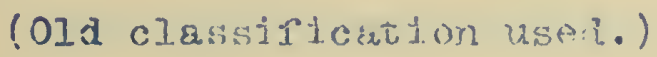

Piarsigf, R.

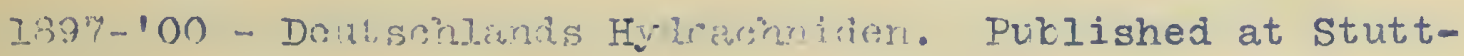
gart in atlas form, 500 pages, 51 pls. (Has a bibliography o1 orle hundred and nine references).

Richters, F.

1902 - Boiträgr zur Kerntris ier Fanna der Umgebung von rFrankfurt. Ber. Senck. Nature. Ges., Yi. 3-26, Taf.

I and II.

Rilay, C. T.

1877 - The Ioridst Mite. Rery.U.S. Hritory. Com. pp. 306-313, 12 figs. (Iife history and economic importance given).

Robert, T. C.

1902 - The Tick Fever or Murrain in Southern Cattle. Miss. Agricultural Exueriment Stidilor. BuII. No. 73, 24 pages 2 figs. 

Salmon, D. E.

1899 - Fuperiments mith Texis Fever and Southern cattle Ticks. Repr. from Sixteenth Annual Report of the Bureau of AnimaI Inaiustry, U.S. Department of Agriculture. 52 pages.

Slingerland, M. $\mathrm{W}$.

1895 - The Plum-twig Gall Mite. Can. Entom., Dec. vol. 27, No. 12, pp. 329-336, 1 plate.

Thor, S.

1901 - Zur Systematik der Acarinen familien Bdellidae, Eupodidae, und Cinaxida, . Verta. Zool. Bot. Ges. Weir., V0I. 52, MT. 158-168.

1904 - Norverische Blelilidie I, rehst Notizen über die Synonymie. Zool. Anz., vol. 28, pp. 69-79. (Gives good descriptions of species. Many synonymous species are reaureal).

1905 - Norwegische Beiflidale II. Zool. Anz. JuIi 1905, Bd. 29, $p p \cdot 203-207.6$ figs. (Two new species described).

Trâgåràn, J.

1901 - Arachnina. Zool. Centr., vol. 8, pp. 236-238. Trägår th, I.

1901 - Acariden aus Ägypten und dem Sudan. Results of the Swedish ZonI00jejI Expedition to Eropt and the White Nile. Part 2, Mr. I-3.24. Taff. 1-6 (Descriptions of forty-tree species mostly new ones. Bibliography of four pages. Figures of dissected parts and whole mounts). 

Trägårün, I.

1901. - Revision der von Thorell aus Grönland Spitzhergen und der Bären Irsse I und von I. Koch aus siberen und Novaja Semlja beschriebenen Acariden. Zool. Anz., vol. $25, \mathrm{r}, 56$.

1902 - Zur Iitoralen Arten der Gattung Bdella Latr. Stockholm, 24 ipages, 2 pls.

1904 - Monographif ifr aristischen Acariden. Inaugural Dissertation zur Erlangung der Doktorwe Je. Jena, 32 figs., I plate. (Descriptions of ninety-six species many new ones).

Warburton, C. and Peance, N.D.F.

1905 - New and Rare British Mites of the Family Oribatidae. Proc. Zool. Soc. Lond., vol. 2, pt. 2, pp. 564-569, pls. 19,20. (Contains descriptions of seven new species and four rase ones).

Wolcoti, R. H.

1893 - New American Species of the Genus Atax. Reprint from Zoological Bulletin, vol. I, No. 6, pp. 278-285, 6 figs. (Describes seven new species).

1902 - The North American Species of Curvipes. Studies from the Zoologicel Laboratory of Uni. of Neb. no. 50, pp. 202-256. Reprint from Trans. Amer. Micro. Soc., 4 pls.

zürn, F. U.

1897 - Ueber Milben die Hautkrankheiten bei Hausthieren hervorrufen. 20 fies., 51 nages. 



\section{IIST OI ABBREVIATIONS.}

A.M.S. Ital. Rep.

Acar1, Myriopoda et Scorpiones hucusque in Italia reperta. ( $A_{2}$. Berlese)

Acar. Ital.

Acari Italiani. (G. Canestrini)

Amer. Natur.

The American Naturalist.

Ann. Rep. Inj, and Ben. Ins. of Mass.

Annual Report of the Injurious and Beneficial Insects of Massachusetts.

Anl . Sci. Natur. Zool.

Annales des Sciences Naturelles Zoologie.

Arch. Natur.

Archiv fur Naturgeschichte.

Arch. Nus. Hist. Natur.

Archives du Muséum a' Histoire. Naturelle.

Arac. di Nias $\in$ Sum.

Aracnidi di Nias e di Sumatra. (T. ThorelI)

Arac. aj Pin.

Aracnidi di Pinang. (T. Thorell)

Arach. Sib. und ITov. Sem.

Arachniden alis Sibirien und Novaja Semlja. (I. Koch)

Atti d. R.J.nst. Ven. di Sci., Let, ed Ar.

Atti del Reale Instituto Veneto ai Scienze, Iettere ed Artj.

Baust. Acar of . Ung.

Bausteine au Firer Aurofauna Ungarns (L. Karpelles) 

Bib. Zool.

Bi.bIIotheca 7.0010gica.

Ber. Senck. Naturf. Ges.

Bericht der Seucken. Naturf'n Gesell.

BuI1. Soc. Fintom. France.

Bulletin de la Societe Entomologique de France.

Bu11. Soc. Fintom. Ital.

Bullettino della Societa Fntomologica Italiana.

Bull. U. S. Dep. Agr.

Bulletin of U. S. Department of Agriculture. Division of Entomologog.

Econ. Ent. Apt.

Aconomic Fintomology-Aptera. (A. Murray)

Entom. N.

Entomological News.

Ficon. Proc. Roy. Dub. Soc.

Fconomic Proceedings of the Royal Dublin Society.

Can. Frtorn.

Canailan Fintomologist.

Das Tier.

Das Tierreich.

Deut. Fntom. Zitschr.

Deutsche Entomologische Zeitschrift.

Deutsch. Crust. Myr. Arach.

Deutschlands Crustaceen, Myriapoden und Arachniden.

$$
\text { (C. I. } K o \mathrm{C} h \text { ) }
$$

G. Ac . Agrr .

GIi Acari Agrarii. (A. Berlese) 

III. Mus . Nat. Hist.

Illinois Museum of Natural History. (S. A. Forbes)

Int. Ag. Acari ItaI.

Intorno Agli Acari Italiani.

Jag., Swed. Zool. Exp. Egypt.

Jagerskiold, Swedish Zoological Expedition to Egypt.

Jour. Acax. Natur. Sci. Phil.

Journal of the Academy of Natural Sciences of Philadelphia.

Jour. Anal. e Phy.

Journal de Lá Anatomie et de La Physiologie.

Jour. N.Y. Entom. Soc.

Tournal of the New York Entomological Society.

Tour. Roy. Micro. Soc.

Journal of the Royal Microscopical Society.

Krat. Mensch. und Th.

Die Kratamilben der Menschen und Thiere. (M.H.F.Fwistenberg)

Math. Natur. Ber. Tgr.

Mathematische und Naturwissenschaftliche Berichte aus Ugarn, Mem. Nat. Acad. Sci.

Memoirs of the National Academy of Sciences.

Micr. and Rev.

The Microscope and its Revelations. (Carpenter)

Mon. Ark. Acar.

Monographie der Arktischen Acariden. (I. Tragardh)

N. Acar. Ital.

Nuovi Aracnidi Italiani. (G. Canestrini)

N. Sp. Gen. Derm.

Nuove Specie deI Genere Dermaleichus (G. Canestrini) 

Proc. Cal. Acad. Sci.

Proceedings of the California Academy of Sciences. Proc. Entom. Soc. Wash.

Proceedings of the Entomological Society of Washington. Proc. U. S. Nat. Mus.

Proceedings of the United States National Museum. Proc. Z,ool. Soc. Iond.

Proceeiings of the Zoological Society of London.

Prosp. Acarf. Ital.

Prospetto deII' Acarofauna Italiana.

Rep.U. S. Fintom. Com.

Reports of the United States Entomological Commissicn. Tij. Neder1. Dierk. Ver.

Tijaschrift der Nederlandsche Dierkundige Vereeniging.

(M. Weber)

Trans. Arer. Fntom. Soc.

Transactions of the American Fntomological Society. Verk. Zool.- Bot. Ges. Wein.

Verhandlungen Zool.- Botan. Gesellschaft in Wein. Zeits. Wissen. Zool.

Zeitschrift für Vissenschaftliche Zoologie.

Zool. Anz.

Zoologischer Anzeiger.

Zool. Centr.

Zoologjisches Centralblatt.

Zool. ergeb. Russ. exp. nach. Spitz. Ar. et ori.

Zoologische ergebnisse der Russischen expedition nach Spitzbergen; Araneat et Oribatidae. (V. Kulczynsk) 



\section{EXPIANATION OF PIATES.}

Plate I, Fig. 1. Holostaspie n.sp. , p. 33.

Plate II, Fig. I. Gamasid n.sp.(?) .

Plate III, Oribata (n.sp.) Fig. 1, palpus; Fig. 2, pseudostigmata and pectinate bristle; Fig. 3 , adult. p.39.

Plate IV, Fig. I, Notaspis n.sp. , p. 45.

Fig. 2, Phthiracarus n.sp. , p. 36.

Plate V, Fig. I, Bdella peregrina Banks, p. 46.

Plate VI, Fig. 1, Bdella tenuirostris Koch, Fig. 2, tip of palpus. p. 50 .

Plate VII, Fig. 1, Bdella tenuirostris tip of tarsus; Fig. 2, mandible of B. Tenuirostris. Fig. 3, Bdella n.sp. , p. 53.

Plate VIII, Fig. I, egg of Rdella n.sp. ; Fig. 2, tip of tarsus of Bdella n.sp. ; Fig. 3, eyes of same; Fig. 4, palpus of same, p. 55 .

Plate IX, Fig. 1, adult of Bdelia n.sp. , p. 55.

Plate X, Fig. I, Actinedaagilis Banks, p. 58.

Plate XI, Fig. I, Bryobia praetiosa. p. 59. 

PLATE I.

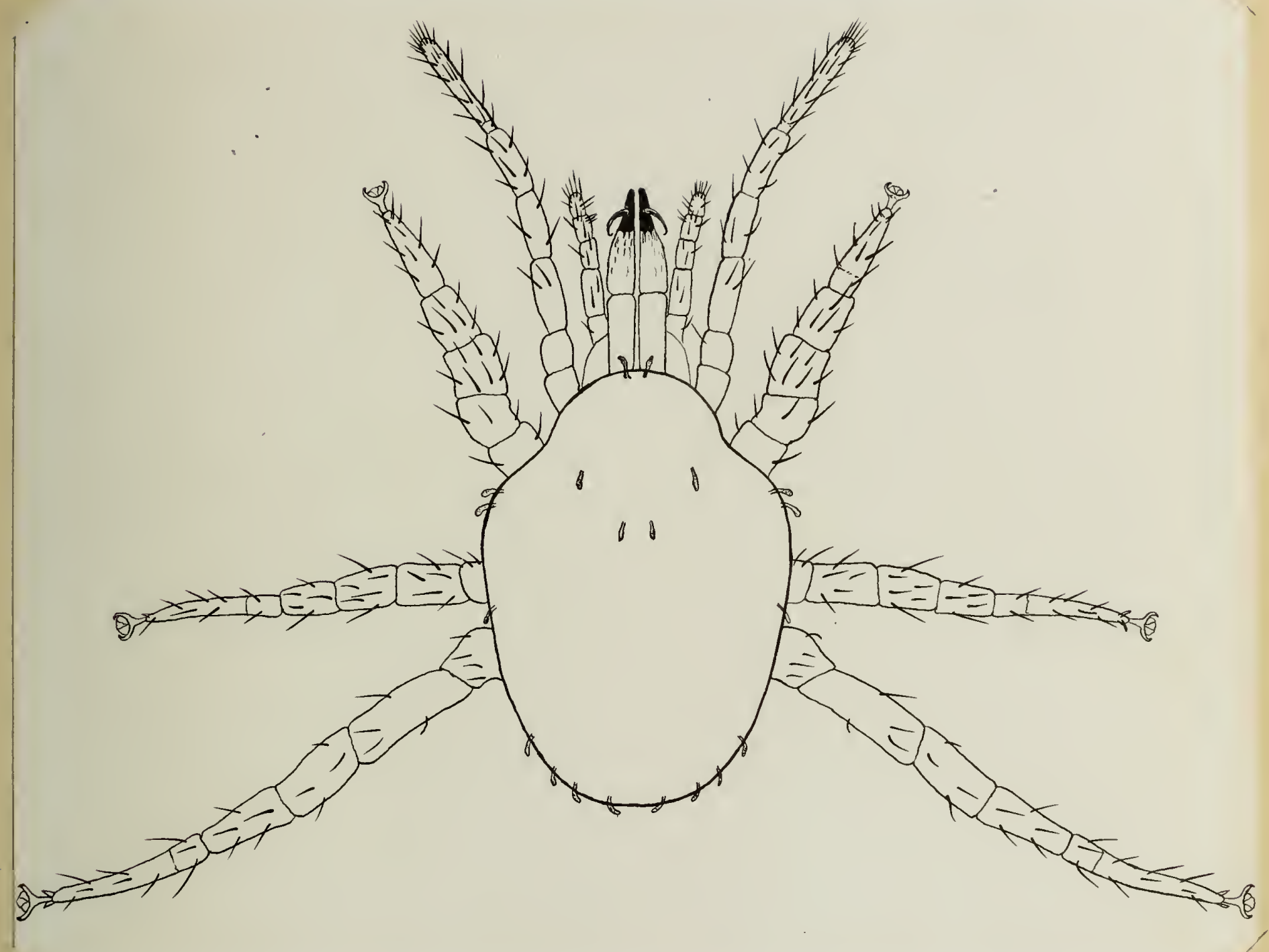

Fig.1. 
4

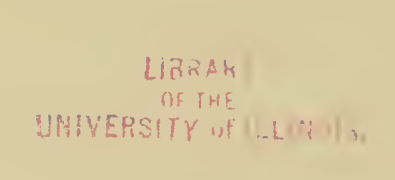




\section{PLATE II.}

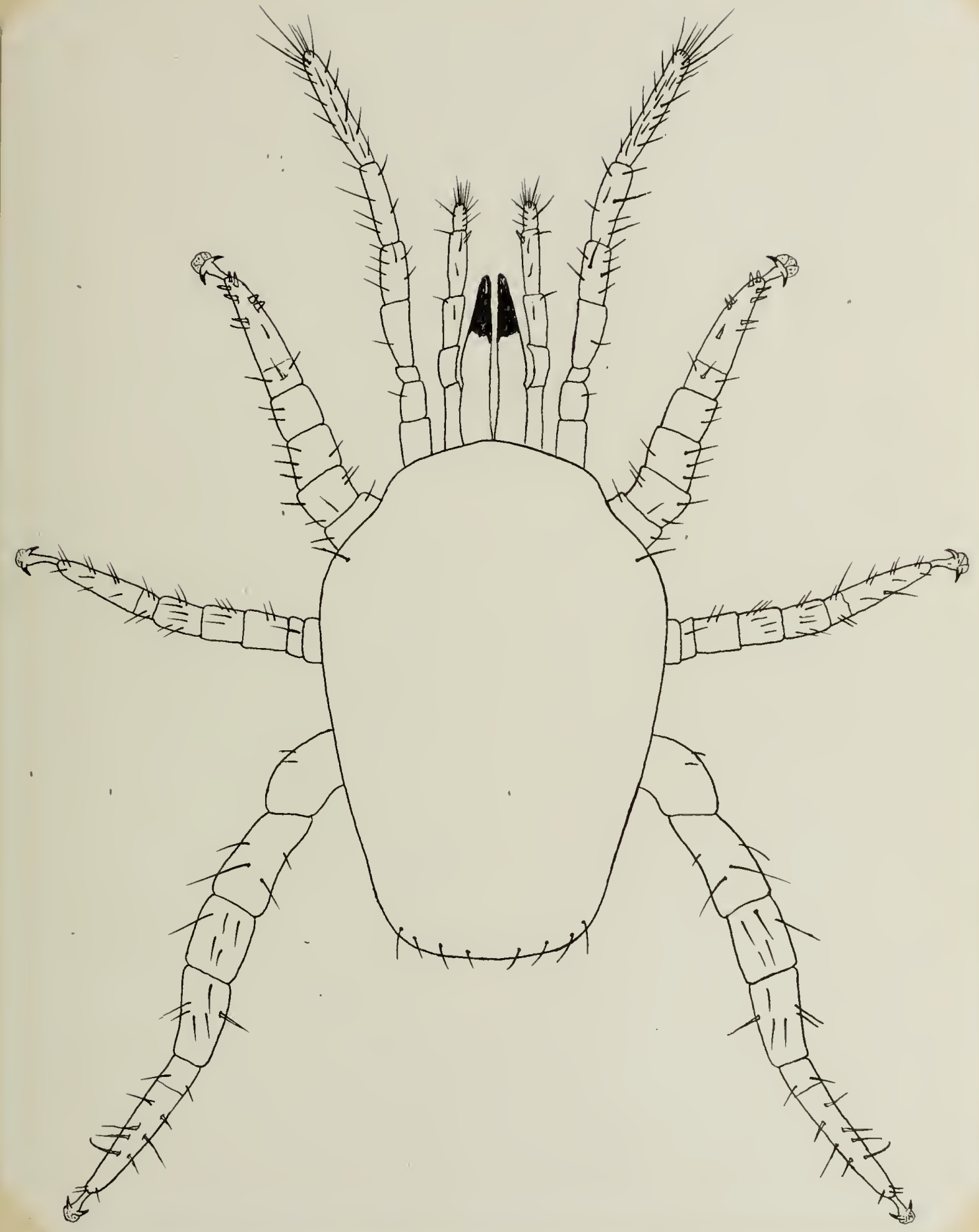

Fig. 1 


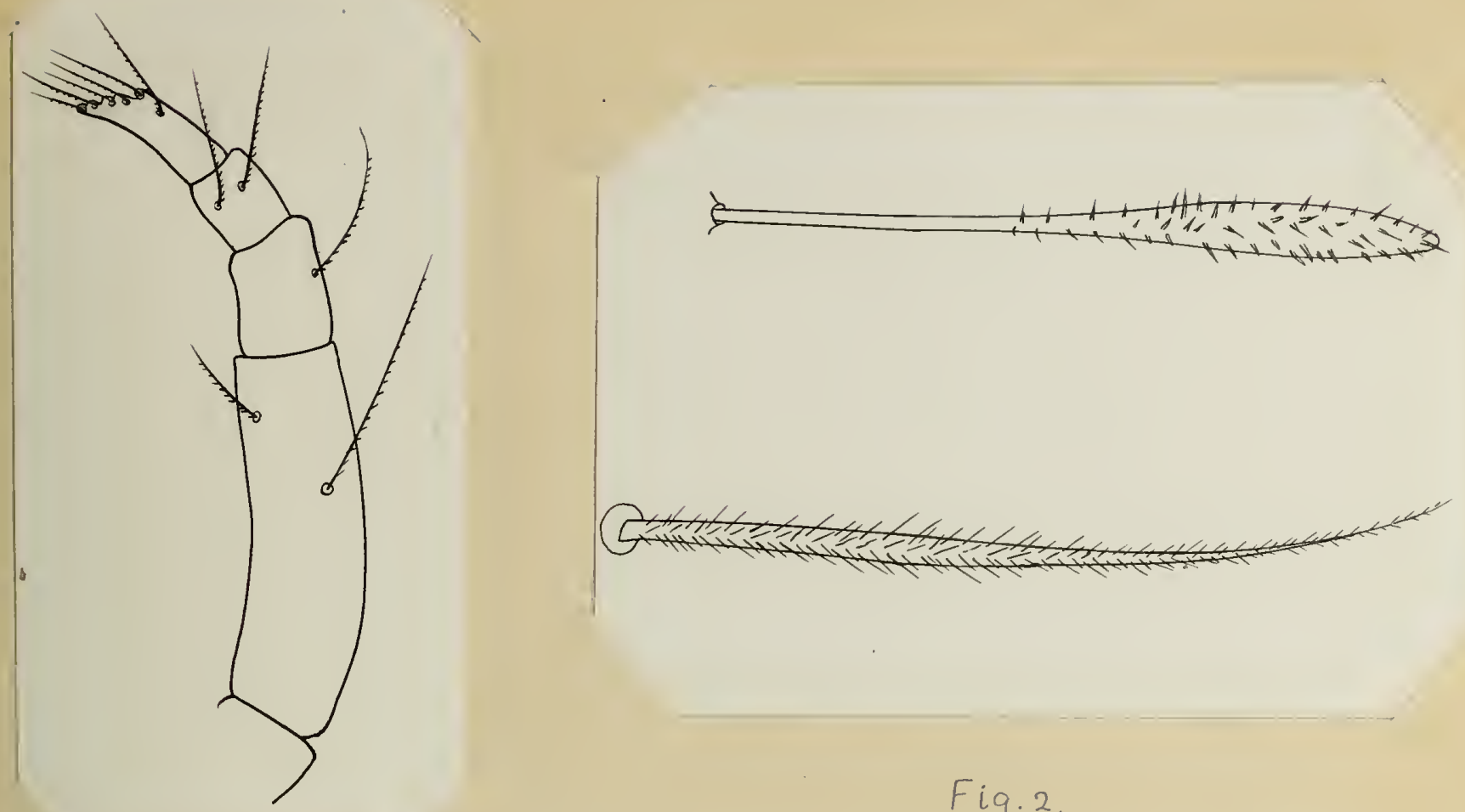

Fig. 2

Fig.l.

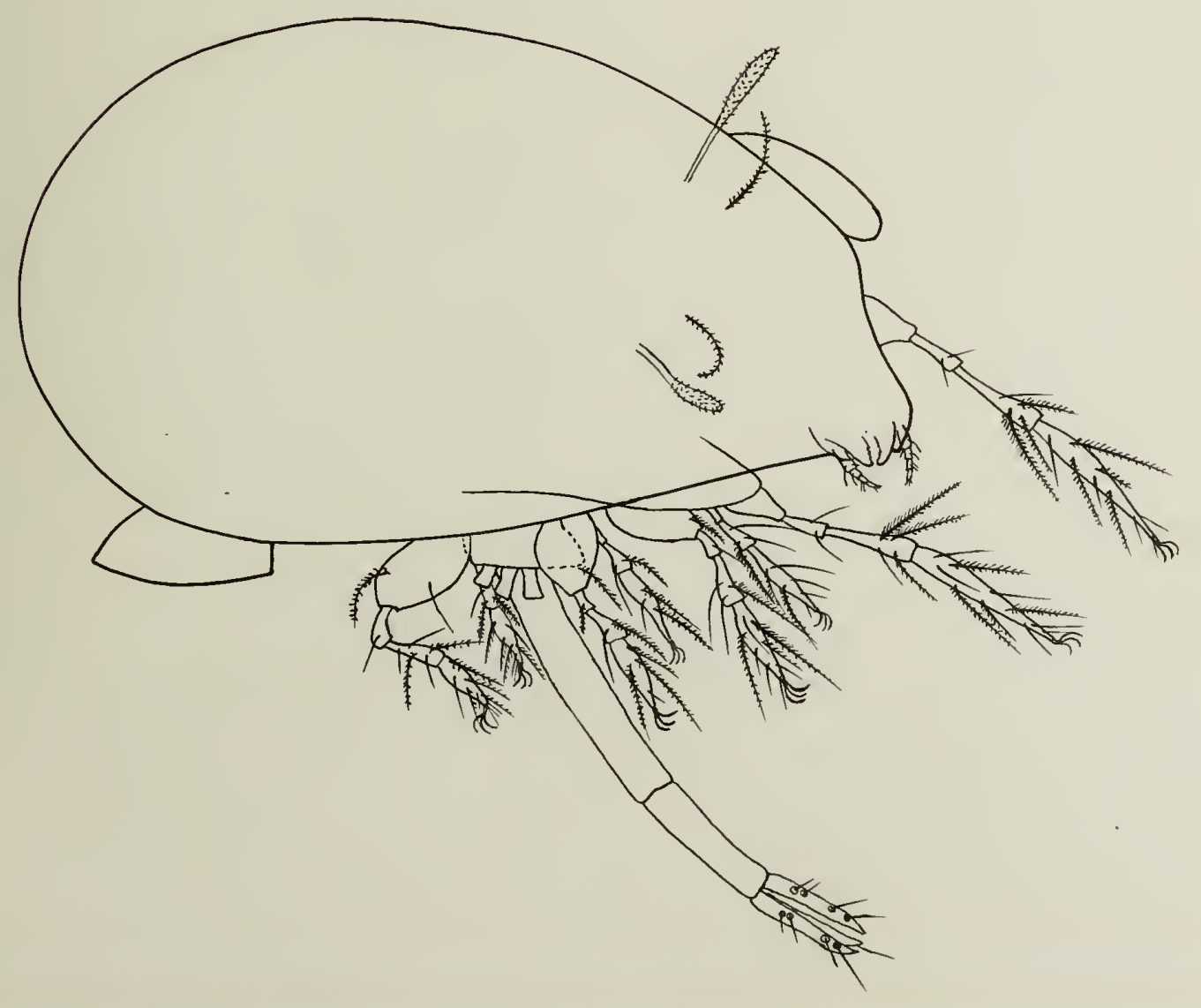





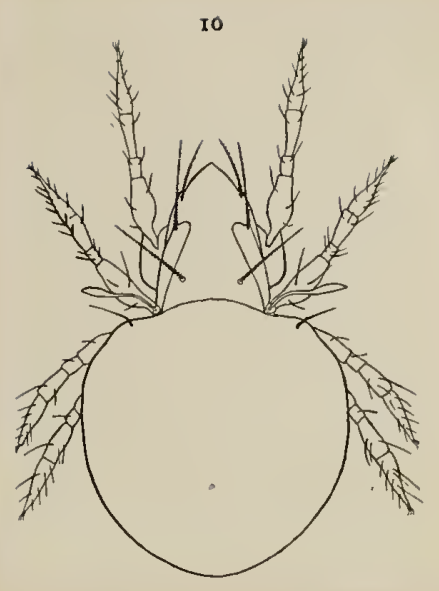

Fig. 1.

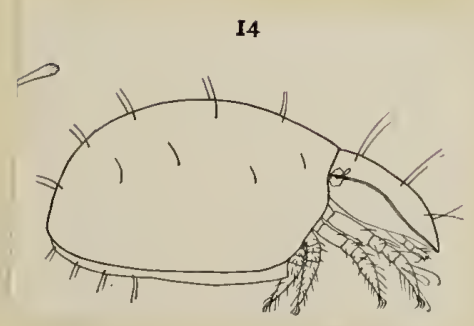

Fig. 2 



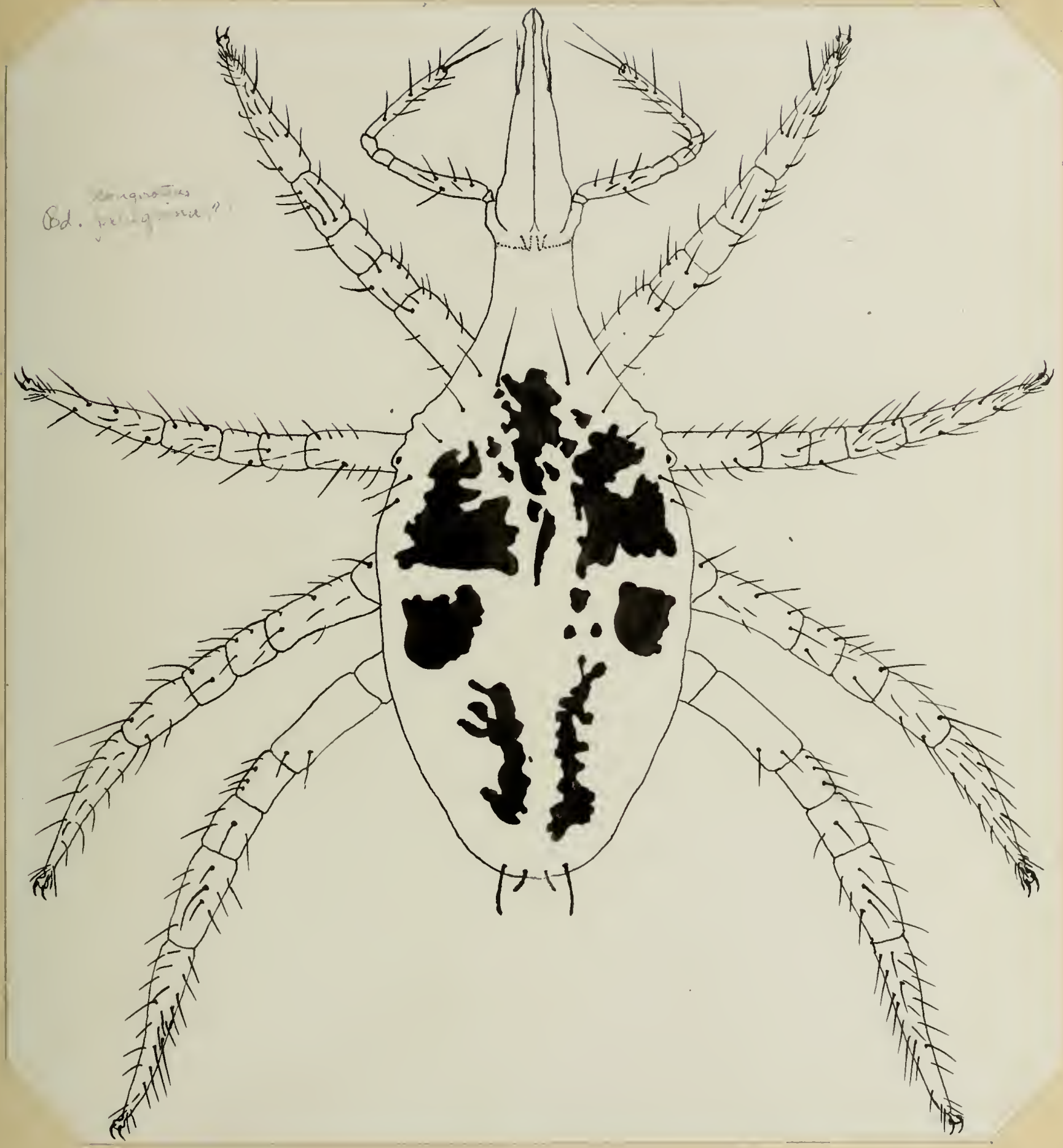

Fig. I 



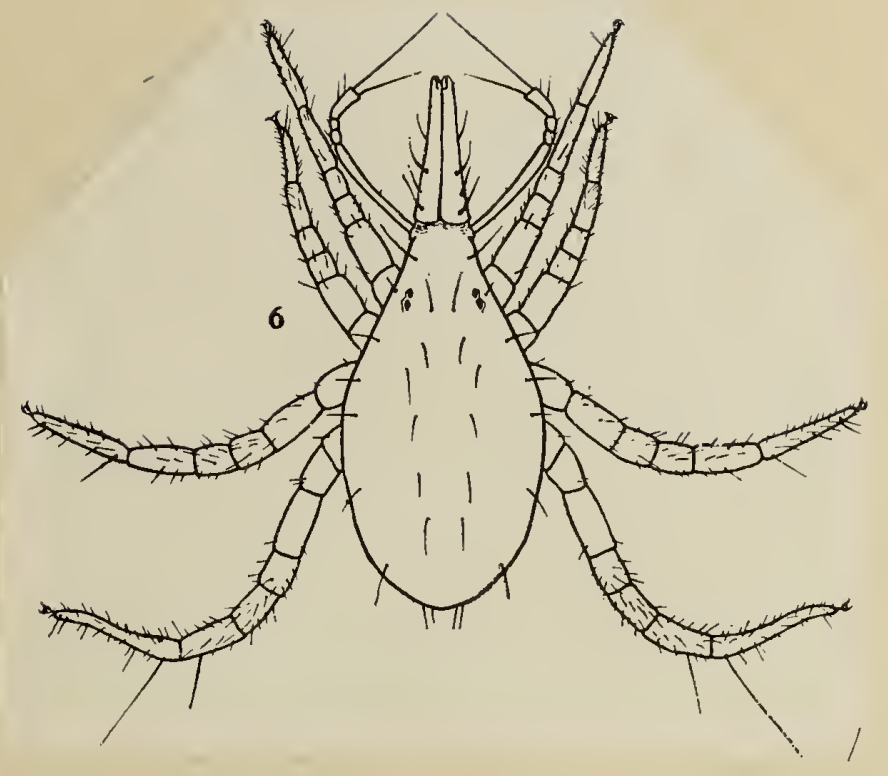

Fig. 1

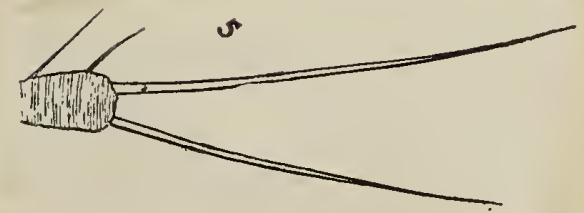

Fig. 2. 


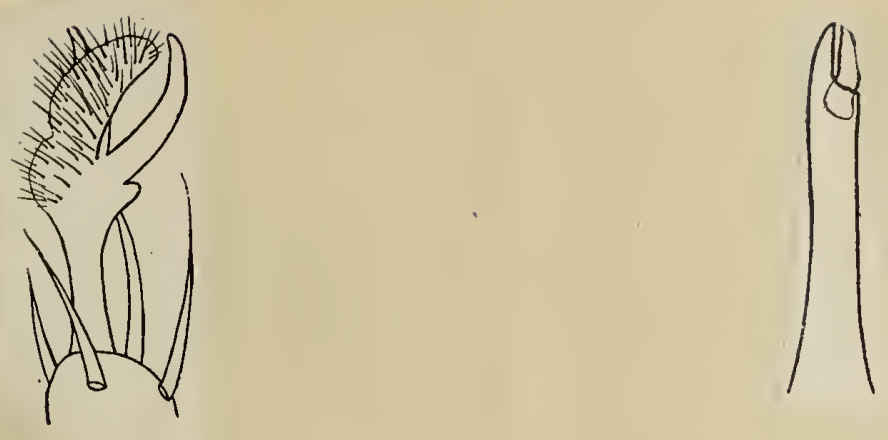

Fig.l.

Fig. 2.

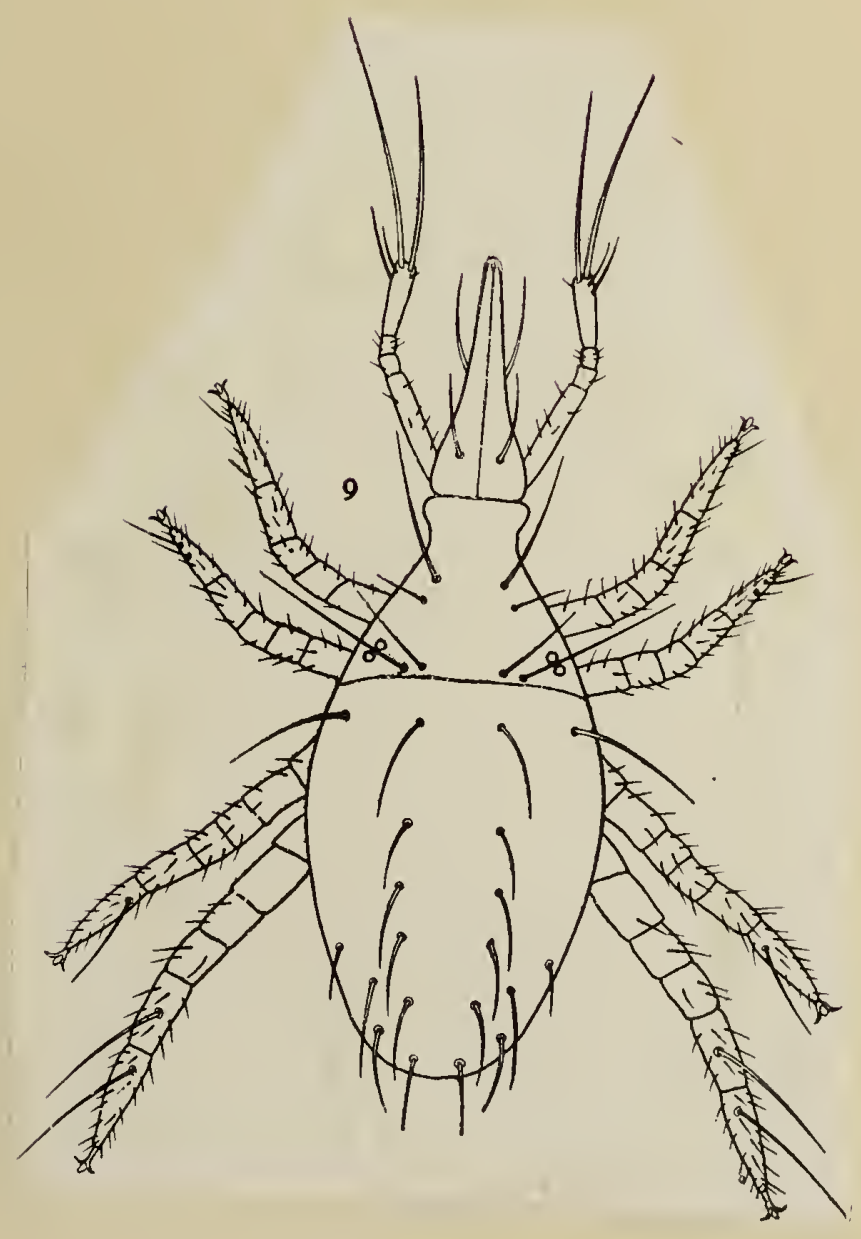

Fig. 3. 
LIBRA,

OF THE
UNIVERSITY OF ILL LUIS. 


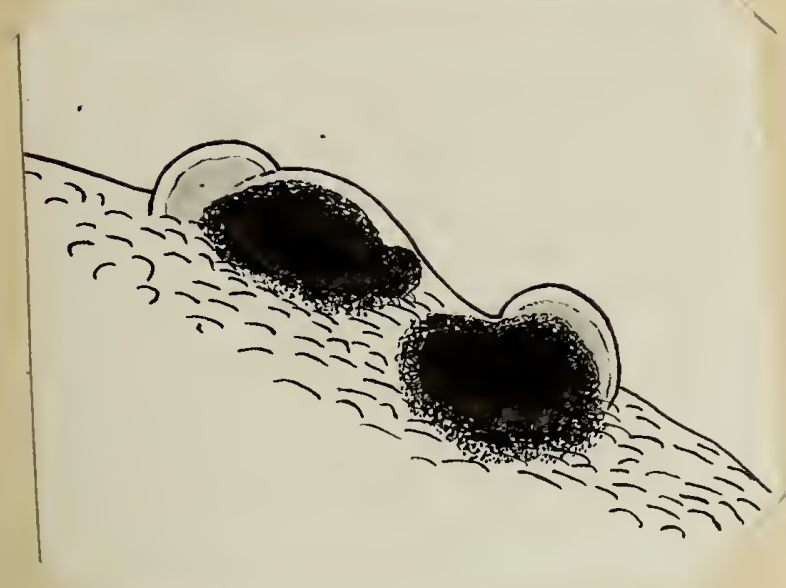

Fig.l.

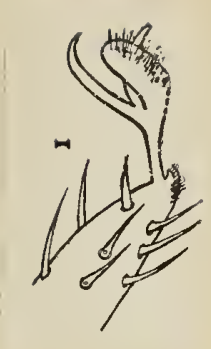

Fig. 2.

Fig. 3

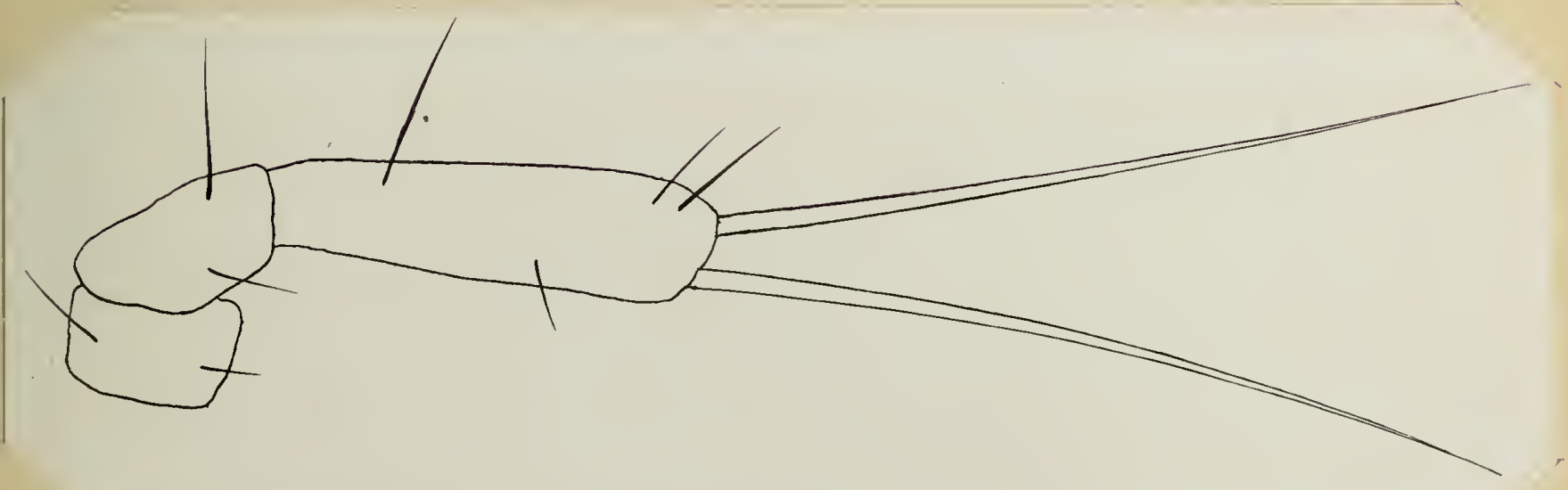

Fig. 4 . 



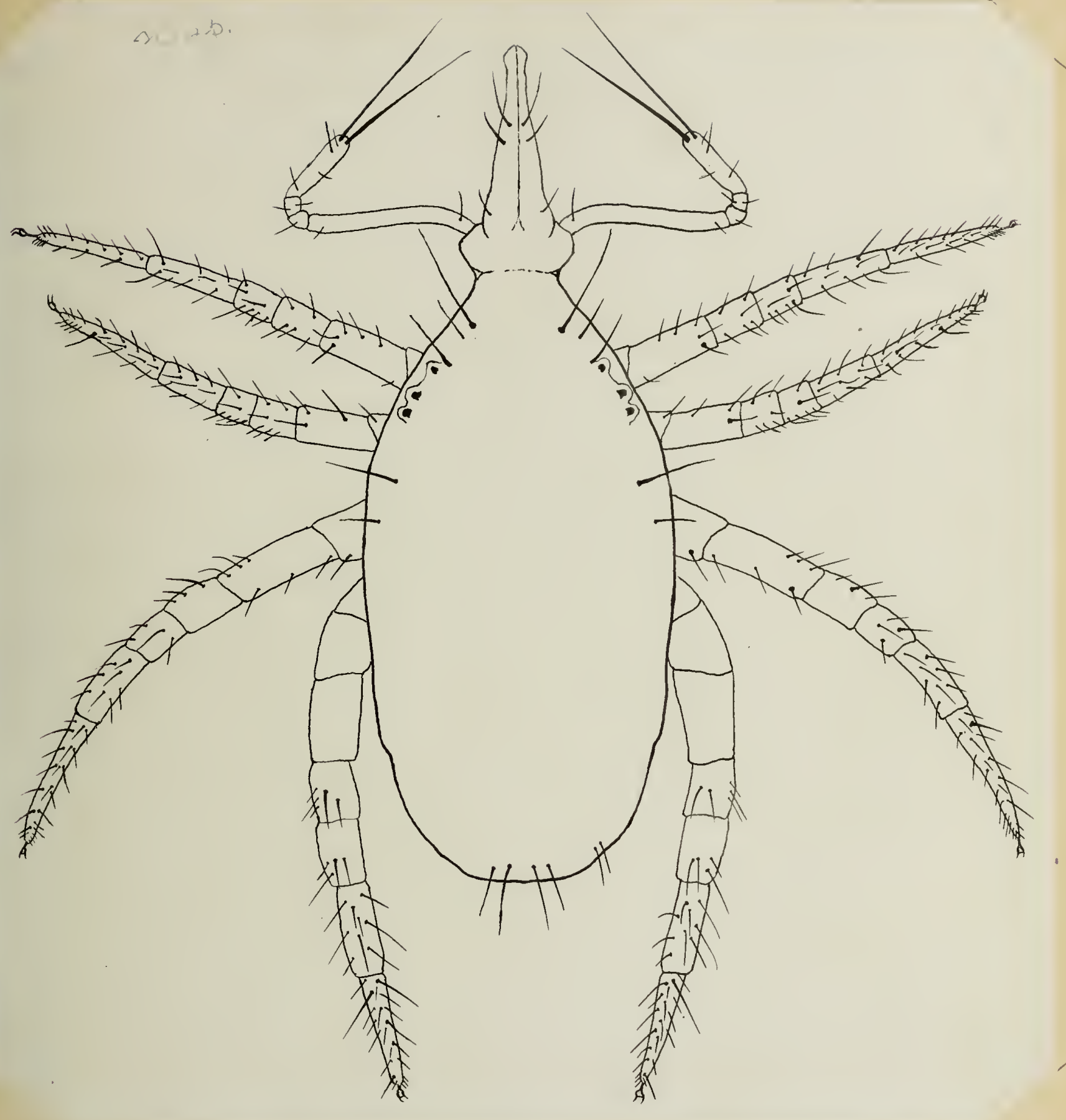

Fig. 1. 



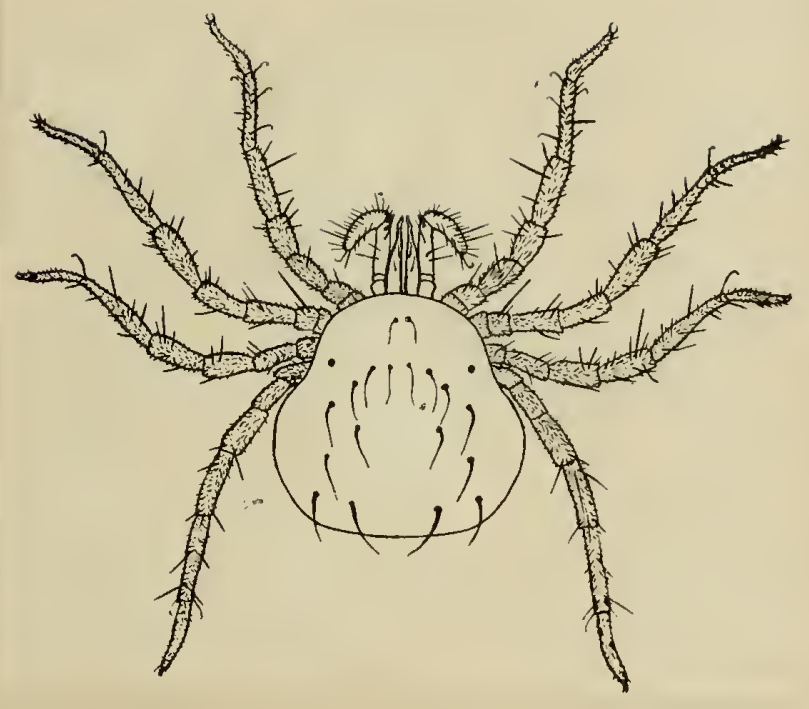

Fig. 1. 
LIPCATYY

तIF THE

UNIVERSITY of LLLINL? 


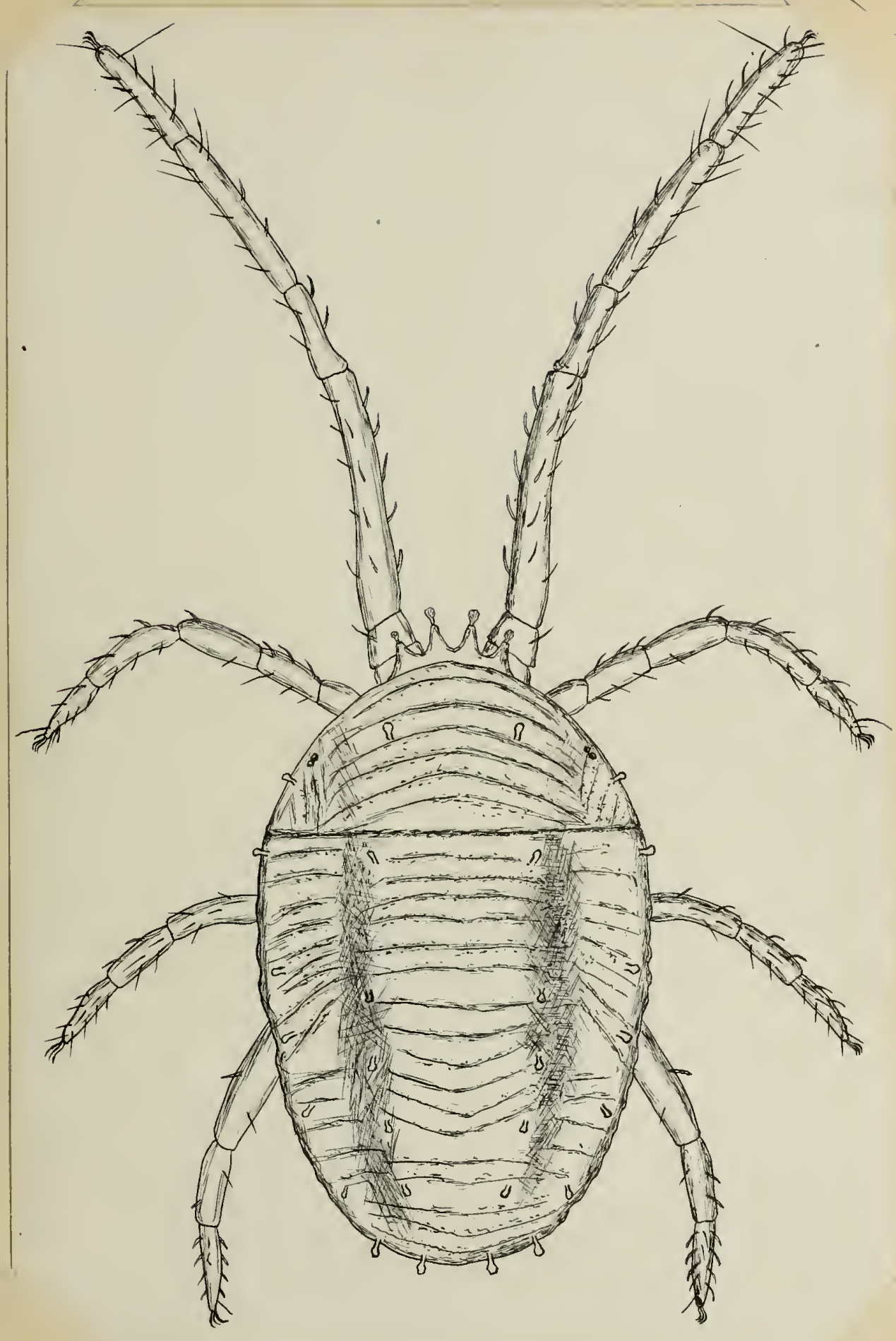

Fig. 1. 

$1,-2-2.25$

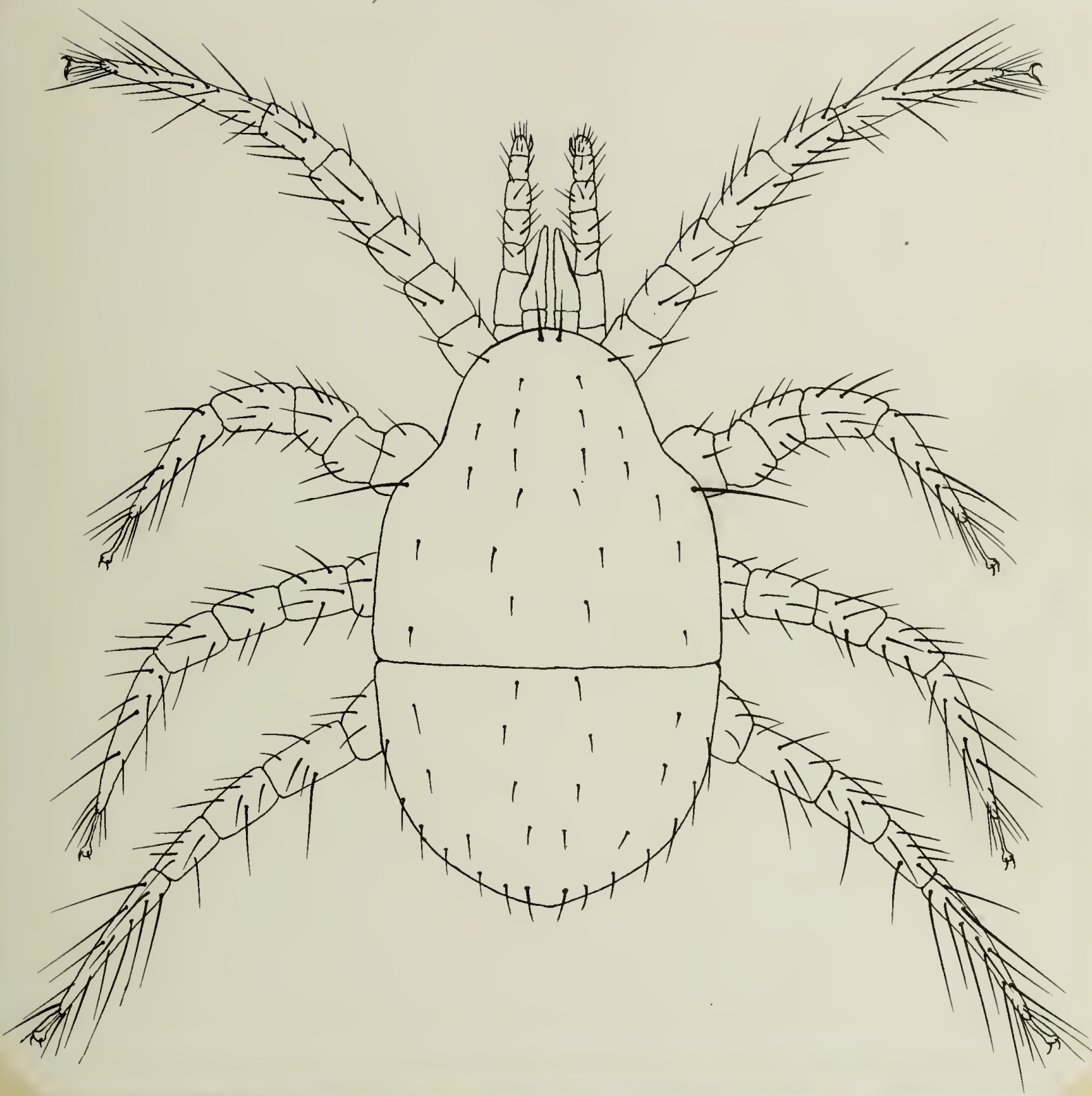

Type of Gamasidae.(I-2-) 



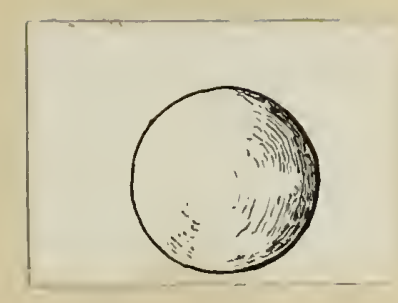

Egg of Tetranychinae.

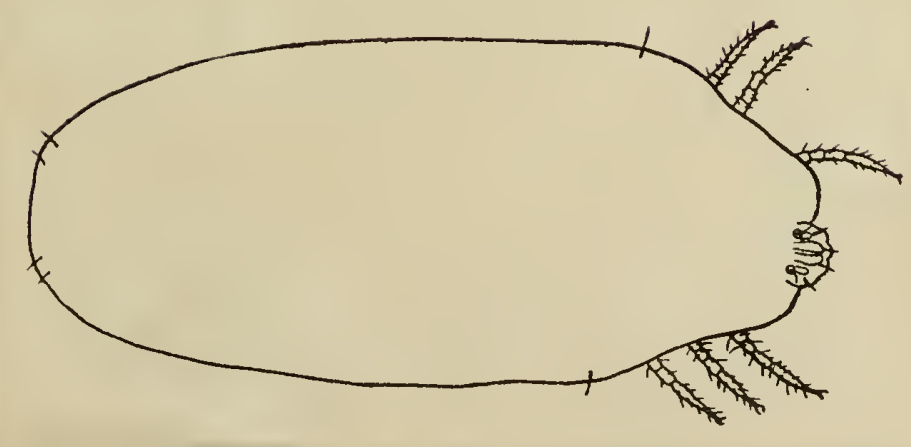

Larva of Dttonia Locustarium. 



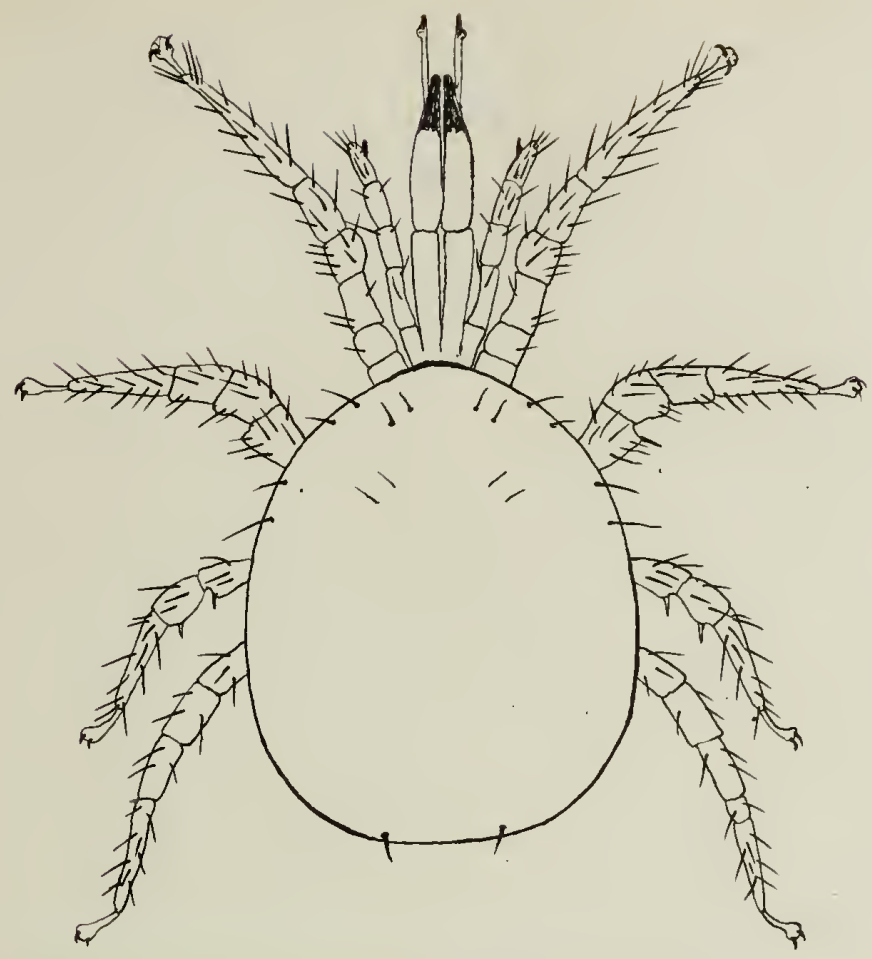

A Lramasid. Fig.l.

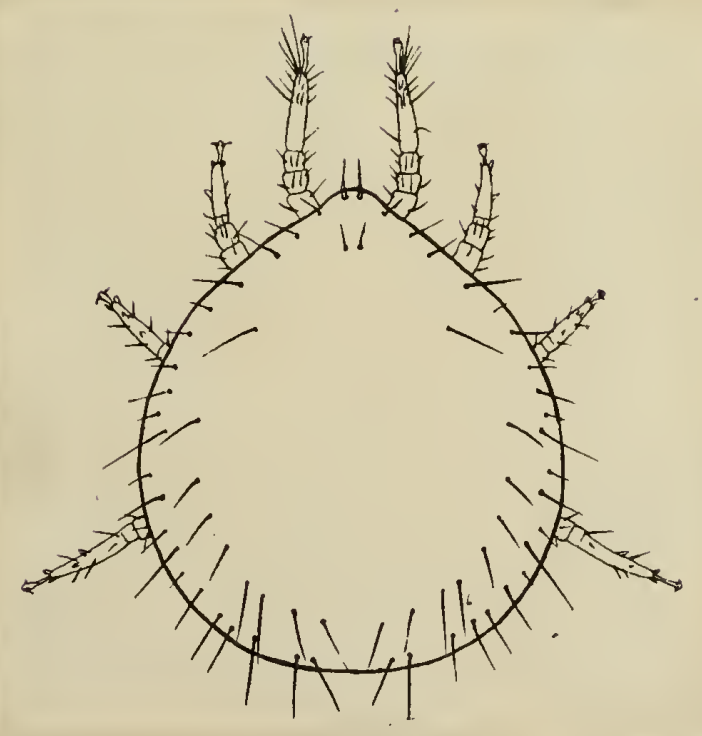



PLATEXV.

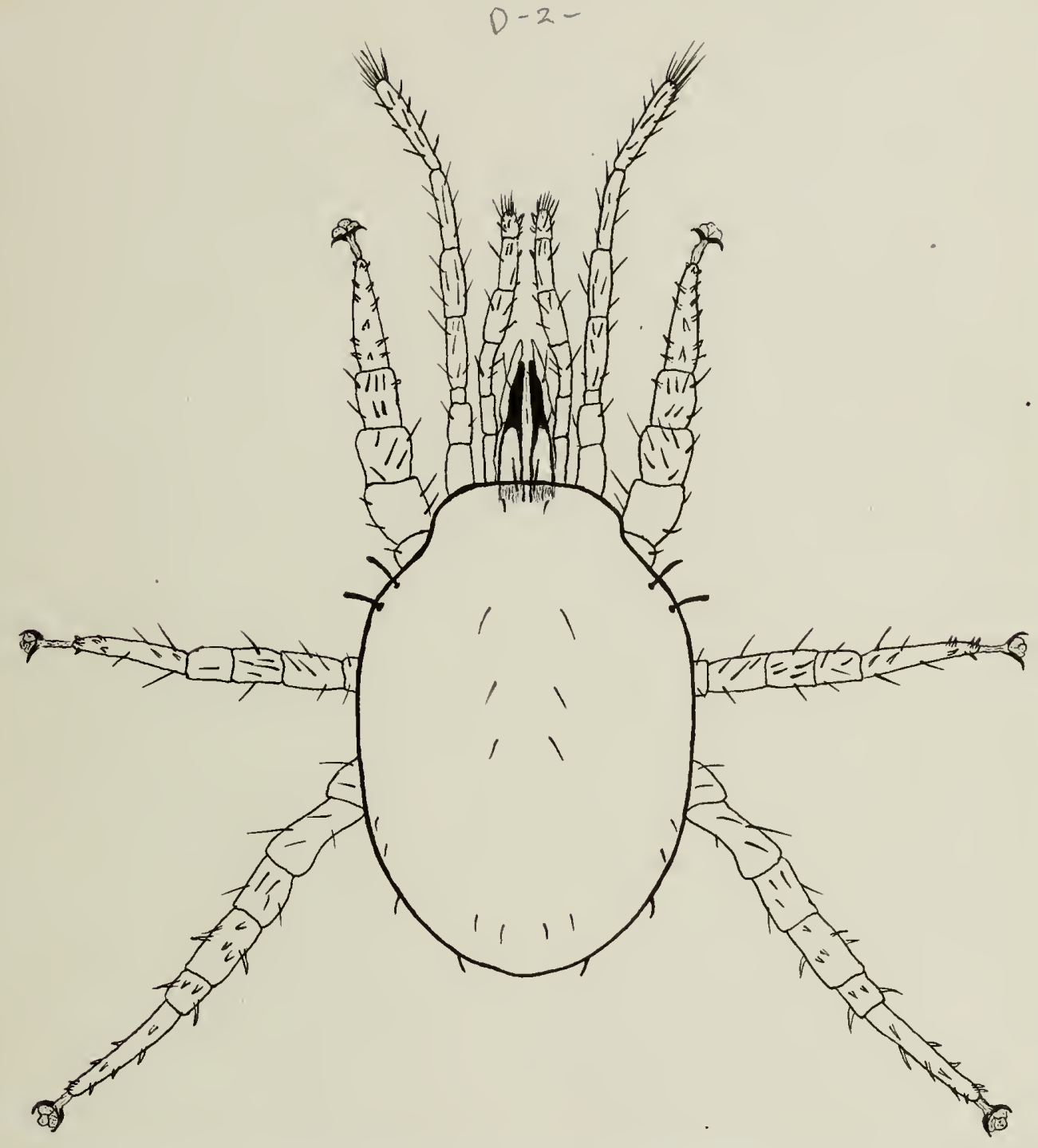

Fig. 1, $\quad$ - 2 



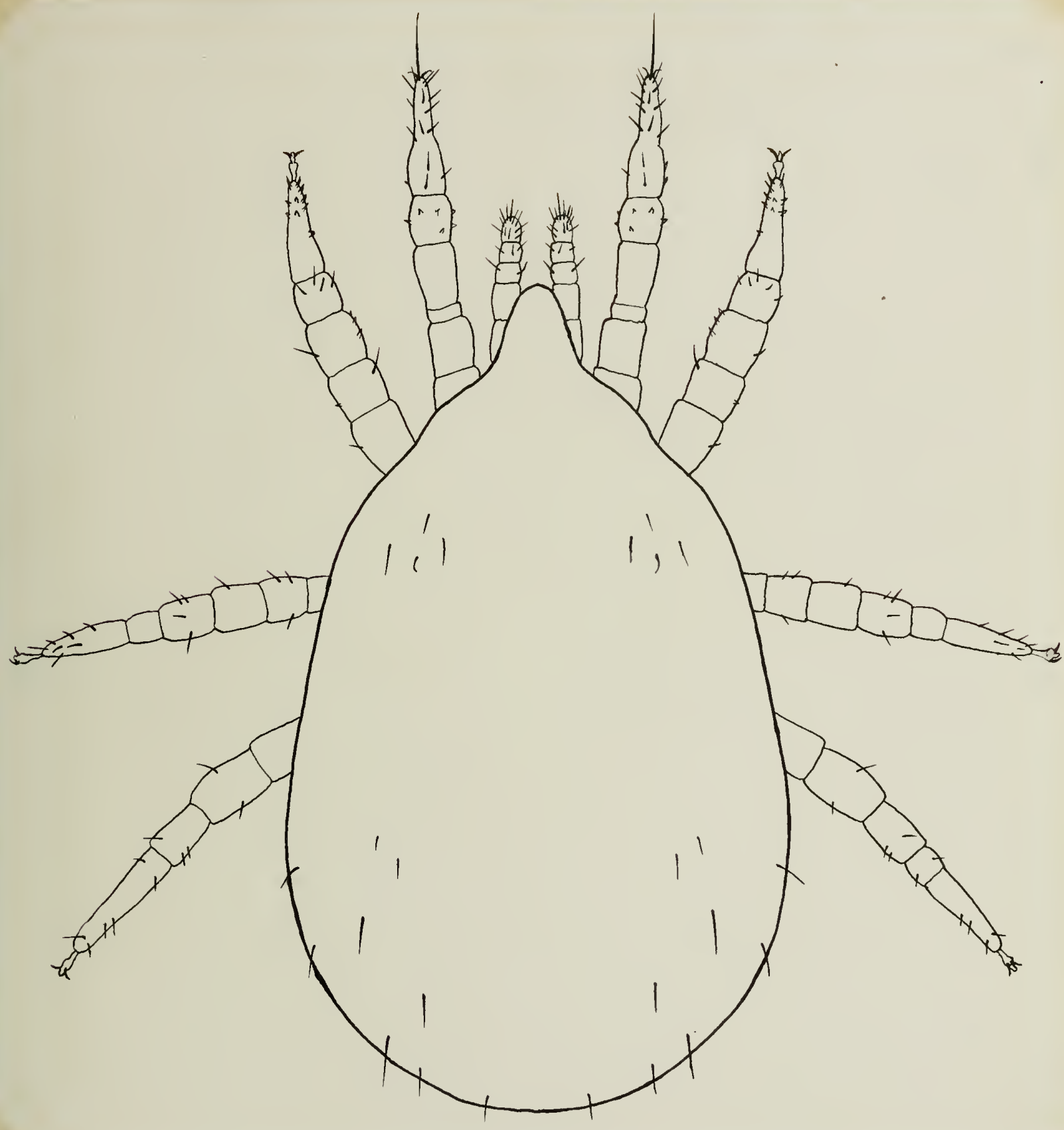

Fig. I. g.-3- 



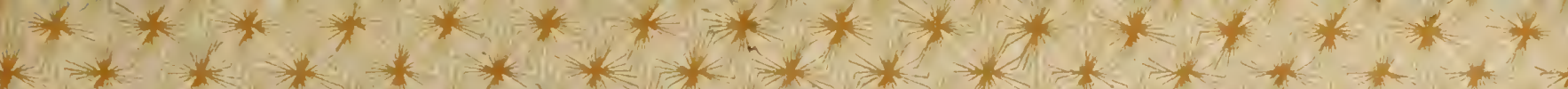

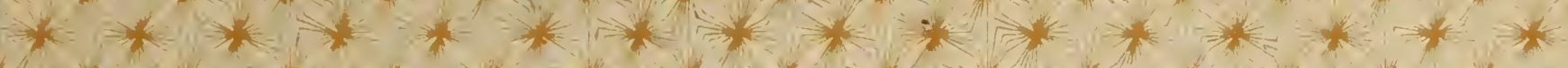

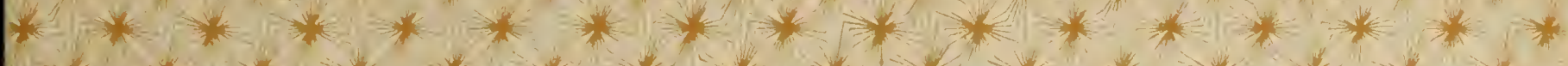

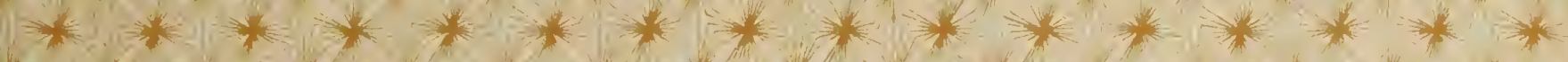

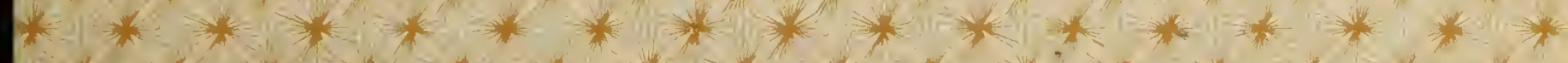

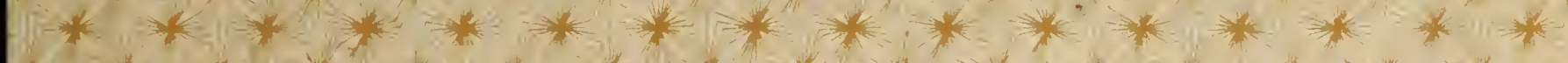
I.

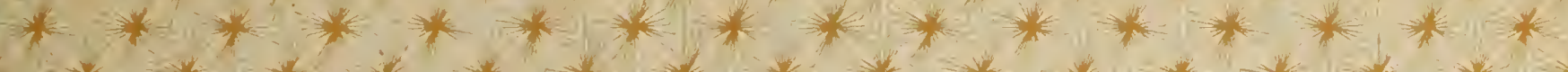

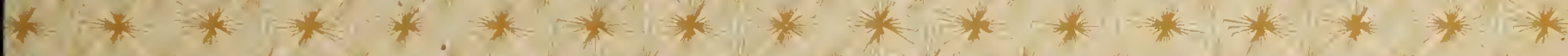

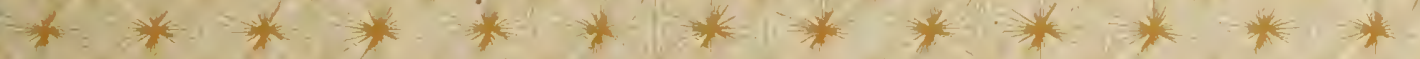

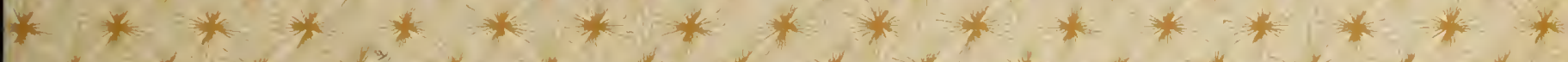

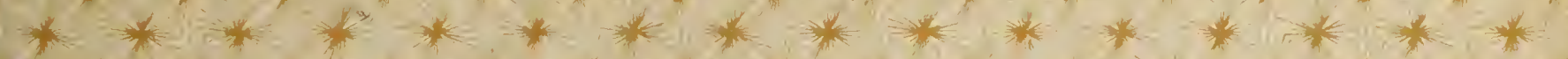

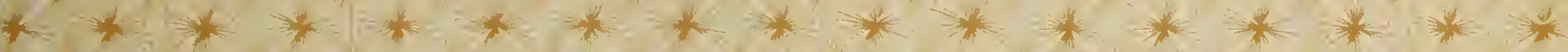

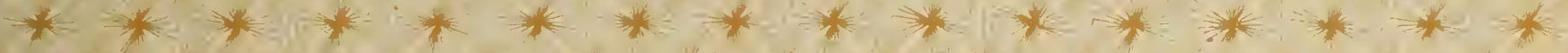

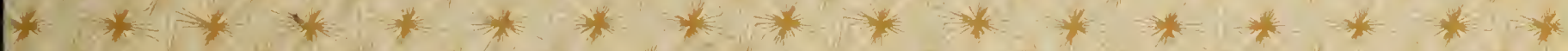

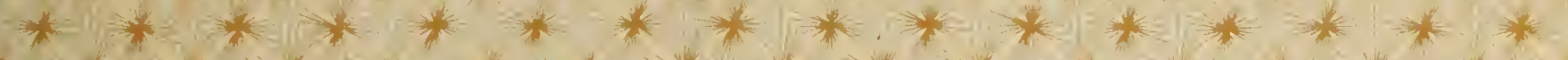

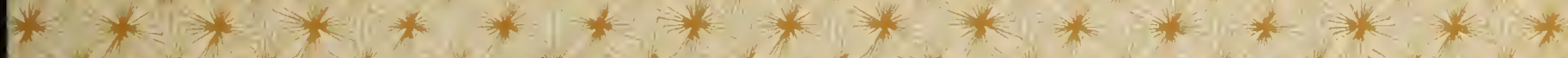

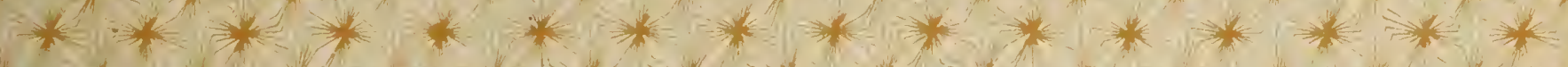

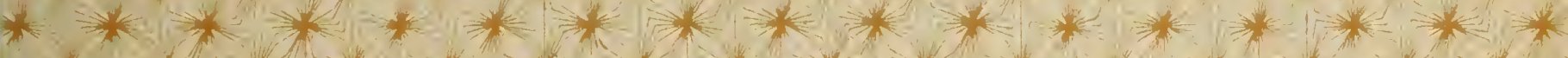

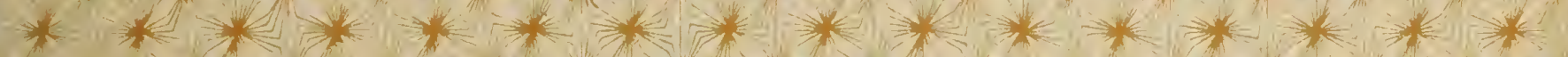

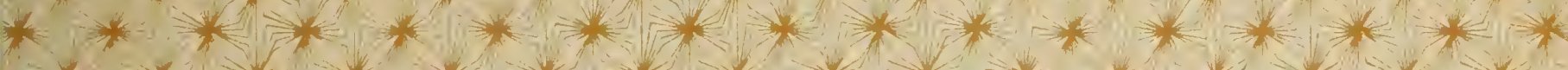

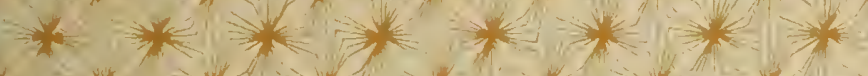

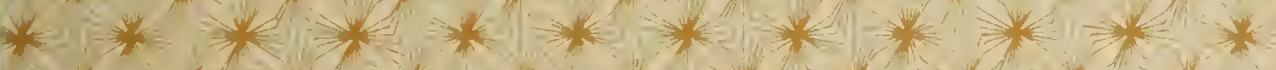

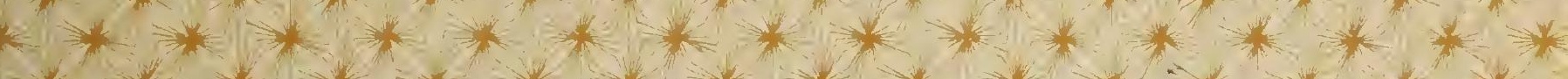

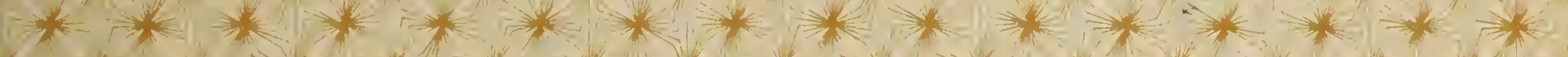

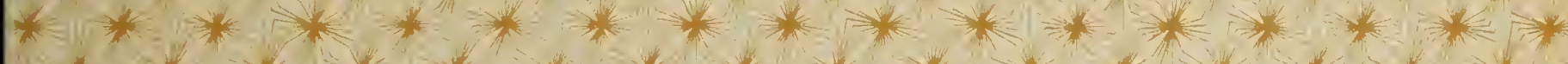
3 *

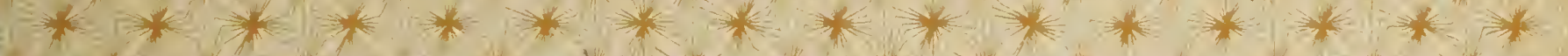
x 1.

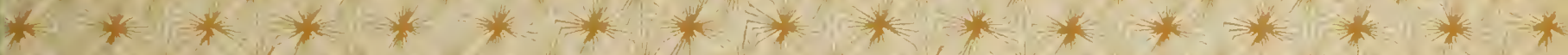

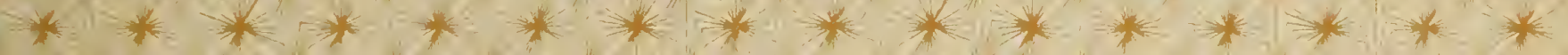

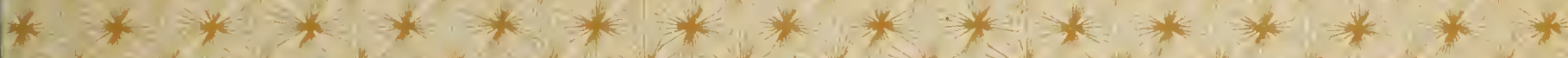

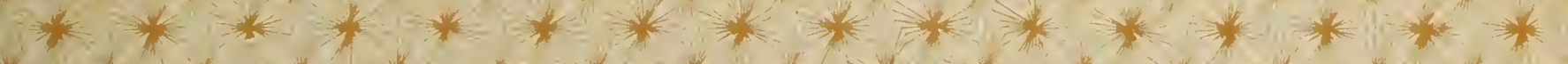

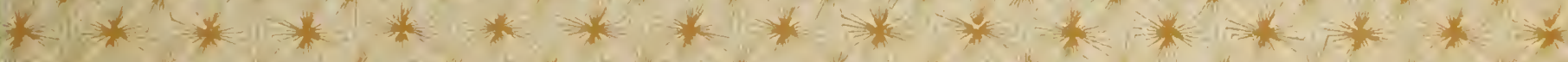
(A.

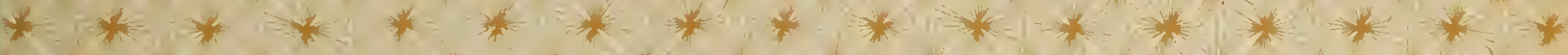

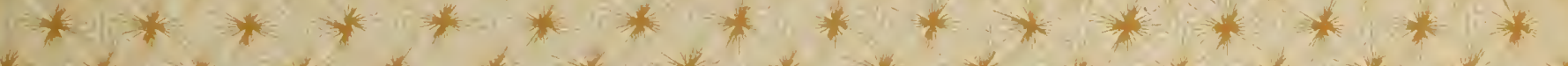

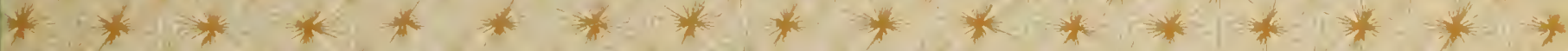

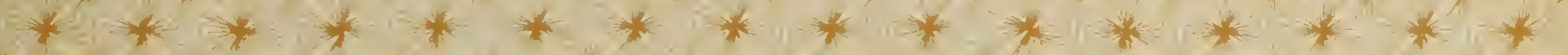
t

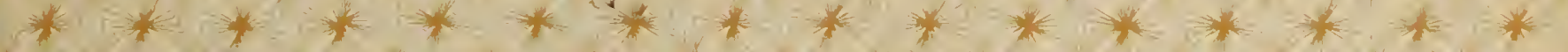

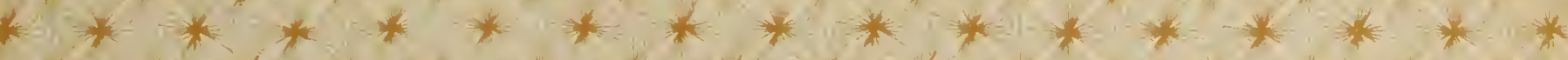

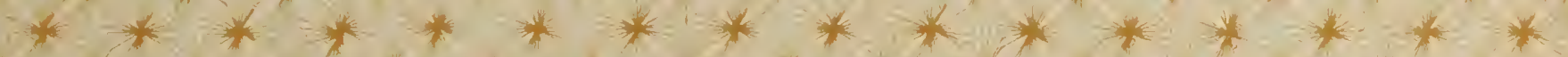


